This item was submitted to Loughborough's Research Repository by the author.

Items in Figshare are protected by copyright, with all rights reserved, unless otherwise indicated.

\title{
A systems perspective on offshoring strategy and motivational drivers amongst onshore and offshore employees
}

PLEASE CITE THE PUBLISHED VERSION

http://dx.doi.org/10.1016/j.jwb.2016.01.005

\section{PUBLISHER}

(c) Elsevier

\section{VERSION}

AM (Accepted Manuscript)

\section{PUBLISHER STATEMENT}

This work is made available according to the conditions of the Creative Commons Attribution-NonCommercialNoDerivatives 4.0 International (CC BY-NC-ND 4.0) licence. Full details of this licence are available at: https://creativecommons.org/licenses/by-nc-nd/4.0/

\section{LICENCE}

CC BY-NC-ND 4.0

\section{REPOSITORY RECORD}

Zimmermann, Angelika, and M.N. Ravishankar. 2016. "A Systems Perspective on Offshoring Strategy and Motivational Drivers Amongst Onshore and Offshore Employees”. Loughborough University. https://hdl.handle.net/2134/20293. 


\title{
A Systems Perspective on Offshoring Strategy and Motivational Drivers amongst Onshore and Offshore Employees
}

\begin{abstract}
Extant research tends to view firm level offshoring strategies and micro level motivational drivers as self-contained units of analysis. By contrast, this paper draws on an inductive study of two global service firms to demonstrate how the implementation and success of an advanced task offshoring strategy depends on certain systemic interdependencies between (a) the strategy, (b) onshore employees' motivation to transfer advanced tasks and (c) offshore employees' motivation to spend effort on their tasks and stay with the firm. We analyse how these three elements interact and produce feedback loops to create an 'offshoring system'. Extrapolating from our findings, we propose how the offshoring system is likely to develop within the external constraints set by the attainable expertise of offshore employees and by client demands.
\end{abstract}

Key words: offshoring, outsourcing, motivation, system, feedback loop, spiral 


\section{Introduction}

With the growing maturity of services offshoring ${ }^{1}$, increasingly complex and nonroutine service tasks are being transferred to offshore destinations (Contractor et al. 2010; Mudambi and Venzin 2010). This development is part of a trend towards a transformational global sourcing strategy, in which offshoring is not only seen as a cost-saving exercise, but is in fact at the very heart of a firm's core value creation and enhancement activities (Clampit et al. 2015; Jensen and Peterson, 2013). Across diverse research areas such as international business, information systems, organizational behaviour and strategic management, researchers have highlighted how such advanced task offshoring strategies can create knowledge benefits and additional cost savings, but at the same time produce transaction costs beyond those created by routine task offshoring (e.g. Gerbl et al. 2015; Dibbern et al., 2008; Stringfellow et al. 2008). A small number of studies have further shown how individual level processes and social dynamics between onshore and offshore employees can determine the degree to which onshore employees support advanced task offshoring in practice (Cohen and El Sawad 2007; Mattarelli and Tagliaventi 2012; Metiu 2006; Zimmermann et al. 2012; Zimmermann and Ravishankar 2014).

Overall, there is now considerable research on strategic considerations for offshoring on the one hand, and on individual level processes that underlie offshoring on the other hand. What is less examined, however, are the potential interactions between an offshoring strategy that follows a group level rationale, and the motivational drivers amongst onshore/offshore employees that may stem from local rationales. Several recent field experiences point to the likely presence of such interactions. For example, US onshore employees are known to be motivated by a set of fundamental fears and insecurities when required to train offshore employees and therefore prone to resisting offshoring strategies (Thibodeau 2014, 2015). Similarly, Indian offshore employees who are top-ranking graduates of prestigious engineering colleges can be solely motivated by the prospect of undertaking creative

\footnotetext{
${ }^{1}$ In this paper we conceptualize offshoring as the transfer of tasks from an onshore unit (typically in Europe or North America) to an offshore unit (typically in an emerging economy). Offshore units can either be subsidiary units of global MNCs or independent service providers.
} 
and challenging tasks and their commitment to the offshoring strategy, contingent upon the availability of such tasks (Ravishankar et al. 2010).

In this paper, we argue that it is necessary to consider offshoring strategies and employee level motivations in relation to each other, in order to better understand the implementation and success of an advanced task offshoring strategy. Our claim is grounded in an inductive qualitative study of two service companies, which examines how department level offshoring strategies, motivational drivers in onshore units, and motivational drivers in offshore units depend on each other. Our case analysis revealed that the interdependencies of these 'elements' created an 'offshoring system', and through this affected the implementation and success of an advanced task offshoring strategy. We extrapolate from our findings to suggest how a number of feedback loops shape the dynamics of the offshoring system, within the limits set by certain external resources.

Our research contributes to offshoring research by providing a systemic and more holistic perspective on offshoring strategies and employee-level factors that drive offshoring implementation and success. It also yields new recommendations for practitioners on how offshoring success can be fostered, for example by combining a performance perspective on offshoring with a career perspective, and by creating a joint career pyramid that balances the career aspirations of onshore and offshore employees. In what follows, we will provide a review of strategic considerations for advanced task offshoring, followed by a synthesis of current insights into employee level processes that have implications for employee motivation in offshoring settings. Throughout, we highlight the lack of research on the interactions between offshoring strategy and such employee level processes. This gap in extant research sets the ground for our methods, findings and discussion sections.

\section{Background: Advanced task offshoring, motivational drivers, and the systems perspective}

\subsection{Advanced task offshoring}

An advanced task offshoring strategy specifies a clear intention to move increasingly complex and non-routine tasks to offshore units. While there are several ways of 
describing an advanced task, we view them as tasks that are complex and nonroutine. Complex tasks are definite pieces of work that include a large set of interrelated subtasks and require comprehensive knowledge and high levels of skill (see Møller-Larsen et al. 2013). Non-routine tasks, in turn, are non-repetitive tasks that are hard to codify (see Kumar et al. 2009). As part of advanced task offshoring, offshore units are typically assigned increasing managerial responsibilities, ranging from project management to the control of customer relations and ownership of independent profit centres. A strategy of moving advanced tasks to offshore units further includes plans for the future distribution of tasks and managerial responsibilities between onshore and offshore units.

Our perspective of advanced task offshoring accords with an activity based view of offshoring (see Johnson et al. 2003), which suggests that offshoring decisions cannot be made at the broad level of functions (such as sales, research and development, or procurement) alone, given the diversity of activities within each element of an organization's value chain. Instead, it is argued that these decisions have to be based on the suitability of particular 'activities' for offshoring (see Dossani and Kenney 2007). To take examples from our case study, such activities can include IT development and tax return services, which comprise specific tasks such as software coding and tax computations respectively.

Previous international business research has explored several key aspects of offshoring strategies such as choice of offshoring locations (e.g. Bunyaratavej et al. 2007; Gerbl et al. 2015; Mukherjee et al. 2013; Schmeisser 2013), governance modes (Kedia and Mukherjee 2007; Luo et al. 2013), geographical configurations (Manning et al. 2015), and organizational (re-)design (Jensen et al. 2013; Lampel and Bhalla 2011; Schmeisser 2013). With regard to motivations for advanced task offshoring, a large body of research across academic disciplines has identified factors that determine the cost-benefits ratio of advanced task offshoring for an organization. This research has considered the potential of advanced task offshoring to reduce transaction costs and generate knowledge benefits for the firm, such as access to local talent and specialist knowledge (see Contractor et al. 2010; Jensen and Pedersen 2012; Kotabe et al. 2009). Studies have also shown how offshoring creates transaction costs, particularly when the tasks offshored are complex (e.g. Gerbl et al. 2015; Møller-Larsen et al. 2013) and non-routine (Murray et al. 2009; 
Stringfellow et al. 2008). Increased complexity and non-routineness of the offshored tasks can contribute to communication and coordination costs (Handley and Benton 2013; Karmarkar 2004) because it necessitates high levels of contextual knowledge, for example, about IT system architectures, end products and cultural specificities (Dibbern et al. 2008). Similarly, non-routine tasks (such as the development of clientspecific software solutions) tend to require problem solving skills and higher levels of knowledge and expertise, and therefore create higher costs for training and ongoing support (Karmarkar 2004). It has also been demonstrated how such transaction costs can be reduced, for example through the social mechanisms of relational governance (e.g. Gopal and Koka 2012) and the development of social capital between onshore and offshore units (Rottman 2008).

This body of research thus highlights a multitude of factors which determine the cost-benefit ratio of advanced task offshoring for an organization. However, there are only a few studies on strategic offshoring considerations that simultaneously examine how these considerations are related to employee level processes. One exception is Bidwell's work (2010; 2012), which notes that actual offshoring decisions are rarely uniform throughout an organization, as business unit managers typically have some discretion over these decisions. Bidwell $(2010 ; 2012)$ draws on the behavioral theory of the firm (e.g., Cyert and March 1963) to point out that organizations consist of coalitions of multiple elementary units which follow local rationales and goals, rather than aligning with the goals of the organization as a whole. In his case study, Bidwell (2012) describes how managers' offshoring decisions were driven by their evaluations of offshoring with regard to costs and benefits for their particular group, rather than the costs and benefits for the organization as a whole. This implies that local rationales and interests can affect onshore managers' motivation for offshoring. Bidwell's research thus indicates how the implementation of a firm level offshoring strategy depends on unit managers' motivations. However, his work does not address motivational drivers at the offshore sites, or amongst middle managers and non-managerial employees. Moreover, he does not expand on what we might call the reverse influence, namely the consequences that these motivations have for the implementation, success, and the further development of the offshoring strategy. 
In a recent study, Manning (2014) touched upon this reverse influence. He described the key firm-level factors that determine how firms react to internal and external challenges that arise during offshoring implementation. Internal challenges in his case study included onshore employees' resistance and offshore employee turnover rates, which are closely related to motivational drivers. Firms in the study worked to mitigate their internal challenges or simply tolerated them. By contrast, a major change in the offshoring strategy, through relocation of operations, occurred almost exclusively in response to external challenges (such as infrastructure challenges), but rarely in response to internal challenges.

In our research, we take a broader perspective, by examining the offshoring strategy in relation to the individual motivations amongst onshore and offshore middle managers as well as non-managerial employees. Put differently, our focus is on the interdependencies between an offshoring strategy and employee level motivational drivers. We thus draw a distinction between the following relevant groups of actors: (1) Senior management at the onshore unit who decide on the offshoring strategy, (2) middle managers and non-managerial employees in the onshore unit who have to put the strategy into practice by transferring tasks to offshore units, (3) middle managers and non-managerial employees at the offshore unit who have to perform the transferred tasks.

\subsection{Motivational drivers of advanced task offshoring}

Extant international business scholarship has identified a range of employee level processes that affect offshoring collaborations. For example, it is recognized that relationships between onshore and offshore employees can be constrained by distances of space and culture (eg. Ceci and Prencipe 2013; Gerbl et al. 2015; Schmitt and Van Biesebroeck 2013) and institutional differences (Sartor and Beamish 2014). However, only a small number of offshoring studies has examined employee level processes that we can classify as motivational drivers.

Some studies note a dissonance between a firm's stated intentions to transfer advanced tasks to an offshore unit and the degree to which members of the onshore unit support this transfer. In these cases, onshore middle managers and technical staff did not believe that it was possible to achieve satisfactory performance at the 
offshore units of their firm, thus doubting the feasibility of the firm's plans for offshoring. For this reason, they refused to move tasks to offshore locations, or they limited their effort in transferring the required knowledge (Zimmermann et al. 2012; Zimmermann and Ravishankar 2014). Similarly, the fear of losing tasks and jobs has been identified as a reason for onshore members to withhold tasks and effort (Zimmermann and Ravishankar 2011; 2014), to unduly criticize their offshore counterparts' work, and to avoid interacting with them as much as possible (Cohen and El Sawad 2007; Metiu 2006). Such fears can also cause onshore members to exclude offshore members from what they regard as their own, higher status onshore group, and to sabotage the offshore unit's chances of performing advanced tasks (Metiu 2006). Although these studies have not examined offshoring strategies per se, it is obvious that such constrained collaboration between onshore and offshore units can make it hard to achieve offshoring targets.

From a theoretical perspective, individuals' expectations regarding the personal benefits and costs of offshoring, such as the possible gain or loss of attractive tasks, can be explained in terms of 'outcome expectations'. According to social cognitive theory (Bandura 1997), outcome expectations refer to the expected consequences of one's behavior. If these outcomes are regarded as attractive, they motivate behavior that is believed to lead to these outcomes (Bandura 1997:125). For example, if onshore members expect that the transfer of certain tasks will lead to desirable performance outcomes and cause limited harm to tasks or jobs at the onshore unit, they are more likely to support the transfer of tasks to the offshore unit.

With regard to offshore units, several studies suggest that their members are generally ambitious and highly motivated to take on higher level tasks and responsibilities in order to gain expertise and to progress in their careers (e.g. Mattarelli and Tagliaventi 2012; Metiu 2006; Ravishankar et al. 2010). Such ambitions create the common issue of high turnover of skilled offshore employees, as they tend to be high in demand and therefore hard to retain at the offshore unit (see Demirbag et al. 2012; Lacity et al. 2008; Lewin and Couto 2007). High attrition of skilled personnel adds to offshoring costs through the need to transfer knowledge repeatedly (Dibbern et al. 2008), difficulties in meeting deadlines, and quality deviations (Zimmermann et al. 2012). 
In an implicit manner, this research hints that the implementation and success of an advanced task offshoring strategy depends on onshore members' motivation to implement the strategy, and on offshore members' motivation to stay with the firm. However, these studies do not focus on motivation of offshore and onshore employees as such. They also tend to describe employee level processes in the onshore and offshore units almost independently of the offshoring strategy, without exploring how these drivers may depend on the offshoring strategy or may impinge back upon it. Moreover, prior studies have not paid much attention to the relationship between onshore and offshore motivational drivers. Our paper addresses these research gaps by examining the interdependencies amongst all three elements offshoring strategy, motivational drivers onshore, and motivational drivers offshore.

\subsection{The systems perspective}

To capture the interdependencies between offshoring strategies and motivational drivers and to explain their combined effect on strategy implementation and success, we adopted a systems perspective. A system is broadly defined as a set of interrelated or interacting elements that form an integrated whole, whereby the behavior of the system as a whole depends on the interrelations and interactions between its elements (e.g. Katz and Kahn 1978). This systems perspective draws attention not only to isolated elements of a system, but to the key interactions and interdependencies between them. A systems perspective is thus well-placed to provide insights into services offshoring and can potentially better explain the interdependencies and dynamic relationships between different components in a given offshoring scenario.

Systems theory (e.g. Sterman, 2000) distinguishes between internal elements and external factors of a system, which both shape its development over time. Interdependencies between internal elements can be bilateral or multilateral, and they can lead to positive feedback loops, i.e. self-reinforcing circular interactions between systems elements which augment or strengthen each of the interacting elements. The interactions can also lead to negative feedback loops, i.e. loops which self-correct and counteract the preceding change, and therefore limit the growth of each element (Katz and Kahn 1978: 26). At the same time, the 
development and growth of the system is affected by external factors that interact with the system, for example factors in the competitive environment of a firm.

The systems perspective has previously been mentioned in passing with regard to offshoring, however without any in-depth analysis. For instance, MøllerLarsen et al. (2013:535) and Jensen et al. (2013:316) refer briefly to the systems perspective when elaborating on the challenges of offshoring-led organizational reconfiguration. They note that organizations are complex systems of interdependent activities that must be effectively coordinated to optimize organizational performance. Offshoring then increases this complexity because it requires decision makers to coordinate and integrate activities across an increased number of international interfaces.

In a similar vein, Luo et al. (2012) point out that organizations are open systems that face high complexity and uncertainty through business process outsourcing, particularly when the outsourced tasks are complex and highly interdependent. Going a step further, they suggest that provider and client firms have to achieve business process integration by creating a joint system in order to deal with this complexity and uncertainty. The authors hence define business process integration as the extent to which provider and client firms build 'an efficient and unifying system under which they mutually support, coordinate, and collaborate for designated business processes and related activities' (2012:50).

In this paper, we similarly view onshore and offshore units as part of the same system, but go beyond exploring particular organizational configurations and business process systems. Here, we focus more generally on offshoring strategy and on the motivational drivers onshore and offshore as the three core elements of an offshoring system, in order to address the lack of research on employee level motivational drivers and their interactions with offshoring strategy. In our qualitative analysis, the systems perspective enabled us to describe the interdependencies between these three elements and identify certain feedback loops, which demonstrated the cumulative impact of the three elements. In other words, we explain how, by acting as a system, the three elements affect the implementation and success of an offshoring strategy. Moreover, we also identify key external factors in the firm's environment, namely the level of expertise that offshore 
employees could attain, and client demand, which we suggest impact upon the development of the offshoring system over time.

\section{Methods}

\subsection{Rationale}

Given the lack of prior conceptualization of the interdependencies between offshoring strategy and employee level motivational drivers, we developed a grounded model of these interdependences. We used the qualitative case study method, which is conducive to gaining an in-depth understanding of such complex socio-psychological phenomena in real-life contexts (Yin, 2009). In order to develop thorough insights into potential motivational drivers, we drew on our respondents' reported perceptions. By organizing and further interpreting these reports in the light of existing concepts as well as contextual factors, we then arrived at our constructions of the respondents' constructions of their social reality (see Geertz, 1973). Whilst the model developed in this paper incorporates certain elements of extant theory (e.g., the notion of 'outcome expectations' and 'system'), it is to a large extent based on our inductive analysis of the field data (see Strauss and Corbin, 1990).

\subsection{Research setting and respondents}

We followed a purposeful sampling method. In order to provide for diversity and to facilitate cross-sector comparisons in our investigations, we collected primary data in two companies, which operated in different sectors. Both companies had captive offshore units and offshored advanced service tasks.

The first company - ELECTRO - is a large German electronics company that has offshored parts of its software development to a captive unit in Bangalore, India. ${ }^{2}$ At ELECTRO, we interviewed German (onshore) and Indian (offshore) members of two departments. Both departments developed software for automotive car engines.

\footnotetext{
${ }^{2}$ We use pseudonyms to maintain confidentiality
} 
The first department - AUTOCONTROL - developed electronic control units, while the second - AUTOSAFETY - developed the electronics of automotive safety systems. The two departments were spread across different office locations in Germany and in Bangalore. AUTOCONTROL's and AUTOSAFETY's offshoring relationship with their Indian counterparts had started around 1992 and 2004 respectively.

The second company - PROFSERVICE - is a global professional services firm, which operates an offshore subsidiary unit in Bangalore, India. We conducted interviews with UK (onshore) and Indian (offshore) members of two departments in this company. The first department, EXPAT-TAX, assisted with and completed the UK tax returns of their client firms' expatriate employees. The second department, CORP-TAX, delivered corporate tax services to UK based firms. We interviewed onshore members of these two departments in offices which were spread across six different UK cities, and we interviewed their offshore counterparts at the firm's captive unit in Bangalore.

We gained access to interview participants by explaining the detailed selection criteria to our initial contacts in each department, who then suggested suitable participants and facilitated our communication with them. We chose to conduct interviews with onshore and offshore employees who were part of an offshoring collaboration. We included a broad range of hierarchical levels, comprising managerial and non-managerial staff, in order to obtain strategic and managerial level perspectives as well as ground level experiences. Across levels, we interviewed 62 respondents: 15 onshore and 17 offshore members at ELECTRO, and 11 onshore and 19 offshore members at PROFSERVICE. Table 1 provides a more detailed overview of our respondents and their departmental affiliations. At ELECTRO, work within the two departments was performed by teams which developed different software products. At PROFSERVICE as well, the two departments comprised teams, which served particular clients. In both firms, senior management decided on the firm's overall offshoring strategy, and department heads defined the departmental offshoring strategy. However, onshore middle managers in the participating departments enjoyed some discretionary leeway in the degree to which the strategy was implemented. They decided what specific tasks should be allocated to the offshore unit, and they had to agree with offshore 
counterparts which offshore employees would take on these tasks at a certain time. Onshore managers also had to organize the staff and financial resources that were required during the transition period. Non-managerial onshore employees in turn provided the initial training and ongoing support for offshore employees to implement the transfer.

Insert Table 1 about here

\subsection{Data collection and analysis}

The interviews were conducted by the first author in German for the onshore ELECTRO respondents and in English for all other respondents. 56 interviews were carried out face to face in the respondents' offices, whilst the remaining six (three in each firm) were telephone interviews. On average, the interviews lasted for about an hour. The interview guide was semi-structured and detailed, but was modified throughout the interviewing phase. To illustrate, the focus of the initial interviews was on knowledge transfer rather than task transfer, but this focus shifted towards advanced task transfer when this new theme was emphasized by all respondents. All respondents were asked to provide both current and retrospective accounts of their firm's and their department's offshoring strategy, and reasons for variations in its implementation and success. We asked all interviewees the same broad questions. However, managers tended to describe the offshoring strategies in more depth, whilst non-managerial staff provided more detailed accounts of motivational drivers at the employee level. Naturally, the interviews with offshore respondents focused to a larger extent on offshore motivational drivers, whilst those with onshore employees tapped more heavily into onshore motivational drivers. Nevertheless, we also asked our respondents for their views on motivational drivers amongst their onshore/offshore counterparts. Appendix A provides our final interview guide.

The data collection and analysis phases were closely intertwined. We reflected upon each interview carefully, and explored emerging new themes in subsequent interviews. We drafted a preliminary model after the first few interviews, and continuously refined it whenever additional factors or dependencies became 
apparent. At the stage where we had reached our focus on advanced task offshoring strategies and motivational drivers, we were able to compare each of these elements to the literature in detail (see Eisenhardt, 1989). Throughout our data analysis, we structured our data into first order concepts that were driven primarily by the data. From these, we derived second order theoretical categories that were more strongly informed by extant theory. By scrutinizing the inter-linkages between these categories, we aggregated them into third-order, theoretical dimensions. An overview of our resultant data structure is provided in Figure 1, following the example of Corley and Gioia (2004).

Insert Figure 1 about here

More specifically, we noticed during our interviews that respondent explanations regarding career prospects, expected performance, and workload could be described in terms of motivation. Upon closer reading of the motivation literature, we found that the notion of 'outcome expectations' best described these findings. When respondents highlighted how the performance of offshore employees depended also on the degree to which they owned their tasks, we were able to explain this through the notion of 'task ownership'. These concepts helped us in constructing several components of our grounded model. Moreover, our interviewees' reports indicated how certain motivational drivers and their respective department's offshoring strategy depended on each other, which we interpreted in more depth by using concepts from systems theory (e.g., positive and negative feedback loops and carrying capacity).

We carried out the two case studies consecutively (first ELECTRO, then PROFSERVICE), which created an intermediate phase of intensive data analysis. During this analysis period, all interviews of the first case were transcribed and coded through NVivo software, and the preliminary model was developed further to accord with all interviews of the first case. This model then served as a basis for the interviews of the second case, and for the cross-case comparison. Some elements of the model had to be re-defined to enable meaningful comparisons between the two cases. For example, respondents in the ELECTRO case stressed that the ability 
of the offshore unit to handle advanced tasks depended on their members' understanding of automotive technology. This argument corresponded closely with what respondents in PROFSERVICE referred to as 'client-specific understanding'. We therefore subsumed these two similar types of arguments under the more general category 'contextual knowledge', which played the same role across the two cases. Similarly, we categorized specific tasks (e.g., software development and completing tax computations) into the more theoretically grounded labels of task complexity and routineness to allow for better comparison and contrasting.

Our cross-case analysis showed several inter-firm (between ELECTRO and PROFSERVICE) and intra-firm (between departments) differences in offshoring strategy. These comparisons allowed us to define the role of 'expertise' as a crucial resource, which limited the development of advanced task offshoring. Similarly, the more positive career expectations of EXPAT-TAX members as opposed to CORPTAX members in PROFSERVICE pointed us to the demand for a product or service from the client as a factor that impinged upon onshore members' motivation to transfer tasks. Detailed discussions of the main findings with key respondents (seven in ELECTRO and two in PROFSERVICE) confirmed our final model. We deemed our model saturated when it was fully supported by all data and additional changes did not add any explanatory power, indicating that theory and data were sufficiently aligned with each other.

\section{Findings}

In what follows, we first present our respondents' accounts of their respective department's advanced task offshoring strategy. We then point out variations in the degree to which onshore members transferred advanced tasks to offshore units, and thus implemented the strategy. We thus draw a distinction between the formulated offshoring strategy and its implementation. However, it is important to note that the offshoring strategy that respondents described at the point of data collection had developed through an iterative process of strategy formulation and implementation, a process that was shaped by the interactions between offshoring strategy and motivational drivers which we will outline later on. The strategy was therefore to some extent emergent (see Mintzberg, 1978; Mirabeau \& Maguire, 2014). 
To describe the underlying offshoring system, we first present the motivational drivers onshore and offshore, as well as their immediate antecedents and consequences. In the subsequent section, we infer the bilateral and trilateral interactions between the three system elements. This is followed by an extrapolation about the dynamic behavior of the system as a whole. Figure 2 captures the offshoring system in detail.

Insert Figure 2 about here

\subsection{Offshoring strategies at ELECTRO and PROFSERVICE}

Both firms had an explicitly stated, firm-wide strategy of transferring increasingly advanced tasks and managerial responsibility to offshore units. The offshoring strategy (top right in Figure 2) took different forms in the different departments of the two firms, with regard to the levels of task complexity and non-routineness, the level of managerial responsibility currently allocated to offshore units, and plans for the distribution of tasks and responsibilities between onshore and offshore units. Table 2 characterizes the offshoring strategy in each department with regard to (a) the levels of task complexity and non-routineness and (b) the level of managerial responsibility allocated or planned to be allocated to offshore units. Table 2 further highlights the perceived limits to offshoring in each firm and department, as well as factors that determine this limit. Table 3 and 4 describe the tasks, and Appendix B presents a set of quotes to illustrate advanced task offshoring in the two firms in greater detail.

Insert Tables 2, 3, and 4 about here

In both ELECTRO departments, the level of complexity and non-routineness of the offshored tasks had increased dramatically since the beginning of their offshoring operations. Indian counterparts were now responsible for more than simple support tasks such as coding and software integration. In the AUTOCONTROL department, they were now also involved in system integration, with designated experts for system reviews at the offshore unit. In the AUTOSAFETY department, system 
integration and review tasks were in the process of being transferred to the offshore unit. In the near future, both departments also planned to transfer the software function development tasks they conducted for Asian clients. Compared to coding and integration, system integration and review as well as function development were more complex and client-specific, and therefore required a more comprehensive understanding of the software system, architecture, domain, and the end product. For more mature products that required only maintenance rather than innovation, the AUTOCONTROL department had also transferred the complete responsibility and leadership for projects to the Indian subsidiary, and this was increasingly done in AUTOSAFETY as well.

In AUTOCONTROL, which had more experience of offshoring, the additional, long-term aim was to develop the Indian unit into an independent supplier to all Indian and certain other Asian clients, which would involve full project leadership for new products for Asian clients, and financial liability towards these clients. The offshore unit would then be held fully responsible for the quality of the product, and pay for any required rework of faulty products. AUTOCONTROL respondents were very aware of this strategy. At the time of data collection, Indian members were already participating in the direct interface (i.e. communications and coordination) with several Asian clients. In the AUTOSAFETY department, which had less experience of offshoring, there was no explicit strategy of developing the Indian unit into an independent supplier. However, members of AUTOSAFETY explained that AUTOCONTROL was generally viewed as the role model for offshoring possibilities.

In ELECTRO, a clear limitation to offshoring was set by the complexity and context-dependency of the required knowledge, and by the geographical location of the client. Highly complex, system- and domain-specific knowledge was necessary for pursuing the highest level technical tasks, in particular new function development However, only a limited amount of offshore employees were seen to stay with the firm long enough to acquire such knowledge. Moreover, tasks which required an indepth understanding of the client-specific end product could be transferred only in teams that served Asian clients. Given the geographic proximity, it was convenient and financially feasible for offshore members to visit Asian client sites regularly and experience their products first hand, a prerequisite for gaining an in-depth understanding of client specific requirements. This created a clear limit to advanced 
task offshoring as far as development of new functions for non-Asian clients was concerned. Accordingly, the leadership of such projects for non-Asian clients had to be retained onshore (see arrows indicating the offshoring limits for ELECTRO in Table 2).

In PROFSERVICE, the broad organizational aim was to offshore the highest possible amount (that is nearly all) of the tax computation work to the offshore unit, as well as the managerial responsibility of conducting the 'first review' of these computations, and the 'second review' after the initial corrections (see Table 2). In both PROFSERVICE departments, the majority of computation work was already completed at the offshore unit. The organizational strategy for the transfer of even more advanced tasks was less definitive and was interpreted very differently in the two departments.

Computations and reviews in CORP-TAX were inherently more complex and non-routine than in EXPAT-TAX, as they required an understanding of complex tax structures of different client corporations. The two departments therefore took different approaches with regard to the offshore members' involvement with the client. In EXPAT-TAX, offshore members were entitled to gather information and discuss increasingly non-standard requests directly with the expatriate clients. In CORP-TAX, the client interface was located predominantly in the UK. Interestingly, members of CORP-TAX held contrasting views on whether the client interface should be moved to the offshore unit. Whilst some respondents believed that there should be a limit to offshoring when it came to the client interface, others pointed out that it was not a good idea to impose such limits given that certain individuals offshore were already successfully gathering information from the client, and that one client interface had indeed been located fully at the offshore unit. With regard to yet more advanced tasks, EXPAT-TAX aimed to train more and more offshore members to conduct the final review and sign off of tax returns. CORP-TAX, by contrast, had no plans for transferring the responsibility for the final reviews and sign-offs to India.

In this firm, the highest level tasks were described as advisory work, corporate tax accounting and auditing (only relevant to CORP-TAX), developing new services for clients, and acquiring new clients (see Table 2). Out of these, only advisory tasks regarding standard tax returns were occasionally done by offshore members of some 
teams. When asked, respondents stated either that they did not believe the highest level tasks were going to be offshored, or that they were not sure about the firm's long-term plans for transferring these advanced tasks. Moreover, respondents in both departments believed that the firm had no intention of transferring the leadership of a client-specific team, or the financial liability towards clients to the offshore unit (see Table 2, arrows indicating the offshoring limits in PROFSERVICE).

As with ELECTRO, the location of clients was seen to pose clear limits to advanced task offshoring in PROFSERVICE. Respondents in PROFSERVICE agreed that offshore members were able to obtain the detailed knowledge of complex tax rules that was required to complete complex tax computations. They explained however that the geographic distance did not allow offshore members to meet clients easily, and thereby to gain the same level of understanding of specific client requirements that the onshore members possessed.

\subsection{Actual task transfer}

In both firms, onshore middle managers had embraced their respective department's offshoring strategy to varying degrees and had transferred advanced tasks to greater or smaller extents. Some managers deliberately restricted the transfer of tasks to the offshore unit, sometimes in clear opposition to the offshoring strategy. By contrast, other managers actively set up large offshore teams which performed highly advanced tasks. Similarly, at the non-managerial level onshore employees supported the task transfer to varying degrees, by spending more or less personal initiative and effort into training, continuous support, and communication with their offshore counterparts. Alongside these individual level differences, variations in task transfer were visible at the departmental and team levels, which we elaborate in our descriptions below.

\subsection{Motivational drivers in the onshore units}

In the onshore unit, we discerned three motivational drivers of actual task transfer. 
We characterized these drivers as onshore members' outcome expectations about (1) task performance at the offshore unit, (2) onshore members' workload and (3) careers of onshore members (see lower right in Figure 2). In what follows, we will show how these drivers affected actual task transfer, and how they depended on employees' experience of performance and on elements of the offshoring strategy.

\subsubsection{Expectations about performance}

A primary reason for the variations in actual task transfer was onshore employees' varying expectations of offshore performance, i.e. their beliefs that the task could be completed satisfactorily at the offshore unit. Respondents explained that onshore employees had become more willing to transfer tasks over time if they had experienced good offshore performance in the past:

'I think they [onshore employees in general] have also been impressed by the work that's been done in India ... so people are more willing to send work now than they were five years ago.' (Onshore respondent in EXPAT-TAX)

Furthermore, performance expectations were seen to be shaped by the offshoring strategy itself, namely the match between the tasks to be transferred (according to the offshoring strategy) and the level of offshore skills. In CORP-TAX for example, a manager explained that the initial task allocation had not matched offshore skills:

'... Most of our problems, I think, were actually caused by the fact that we were told: "Everything has to go over there at that time, and we were told that the teams over there could do $x, y$, and $z$. And so we put stuff over there, only to discover that they could not do $x, y$, and $z$.'

In some ELECTRO teams also, the ramp up of the offshore operation had reportedly been too fast, leading to a lack of qualified offshore employees to take on demanding tasks. In the eyes of respondents, senior management had in these cases allocated insufficient time for recruitment, training and mentoring of offshore employees. In these situations, onshore employees experienced the advanced task offshoring strategy as unrealistic and withheld tasks wherever possible.

\subsubsection{Expectations about workload}


Our data suggest that the transfer of advanced tasks was also affected by onshore employees' expectations about the workload that this transfer would create. Some onshore managers who expected this workload to be high were seen to refrain from offshoring advanced tasks:

'They'll ... say “... We know we're going to take less time than you to complete the tasks, so we'll just leave it here."' (Offshore respondent in EXPAT-TAX)

Not surprisingly, these workload expectations were closely tied to onshore employees' expectations about offshore performance, and related to this, the perceived match between tasks to be transferred and offshore skills. The less onshore employees expected satisfactory offshore performance, the more they expected that they would have to support their offshore counterparts and correct their mistakes continuously. This workload was particularly high when insufficient time had been allocated for transferring the required knowledge, as expressed by this respondent:

'It is really impossible to capture five years of experience in those one or two months. ... ' (offshore respondent in AUTOCONTROL)

\subsubsection{Expectations about careers}

In all departments, onshore employees' expectation of outcomes for their careers was described as an important determinant of their task transfer. This effect became particularly clear through our comparison between the two departments in each firm. AUTOCONTROL in ELECTRO worked on highly mature products that did not yield many new, innovative tasks, and only a small number of new projects had recently been acquired. Similarly, CORP-TAX of PROFSERVICE was going through a period of very slow growth in many regions of the UK. Our respondents explained that many onshore members in these regions felt that the future of their tasks or even jobs was unsure, making them more reluctant to offshore advanced tasks:

'What I would call passive resistance: There were too many people in the UK who saw jobs in the UK threatened by what we were doing, so the India project really made them feel insecure about their own job. ... that if you do the work in India that's

a job lost in the UK. So there were personal insecurities at a time of very bad economic news. ... And in truth there were some people who just didn't really want 
to be part of the project and who wished to keep the work in the UK.' (Onshore respondent in CORP-TAX)

Fears about job losses in the onshore units were particularly great if members felt that their firm's offshoring strategy did not include clear plans for the future distribution of tasks and managerial responsibilities between onshore and offshore units, which created uncertain prospects for future onshore tasks and responsibilities. An onshore respondent in CORP-TAX described these uncertain prospects as follows:

'In our firm, nobody has ever come along and said: "Right, ok, you got to give all this work to ... [the offshore unit], and we're going to give this to you." All ... [we have] ever seen is things being taken away.' (Onshore respondent in CORP-TAX)

Teams in the other departments (AUTOSAFETY and EXPAT-TAX), on the other hand, operated in a growing market and had therefore gained an abundance of new and challenging tasks. These plentiful opportunities had a positive impact on onshore members' motivation to involve their offshore counterparts in higher level tasks, which allowed onshore members to focus on their new projects.

\subsection{Motivational drivers in the offshore units}

In the offshore units, we identified two motivational drivers which affected both members' task effort and their continued employment at the firm: (1) expectations about careers and (2) task ownership (see left side in Figure 2). Below, we present these drivers and explain how they depended on actual task transfer and on the department's offshoring strategy.

\subsubsection{Expectations about careers}

Members of the offshore units were generally seen to be very ambitious and keen to take on increasingly advanced tasks. A main motive was the prospect of faster career progression, but advanced tasks were also regarded as more interesting and intrinsically rewarding. However, we found certain differences in the extent to which offshore members expected their careers to progress. Like in the onshore departments, we found that employees' career expectations were more positive 
within the AUTOSAFETY and EXPAT-TAX, where department heads had broken the firm's offshoring strategy down into transparent plans for the future distribution of tasks and managerial responsibilities between onshore and offshore employees, with clear prospects for the allocation of higher level tasks and responsibilities to the offshore unit. Moreover, offshore employees in these departments were content with the extent to which their onshore colleagues had transferred advanced tasks to the offshore unit. Accordingly, respondents in these departments explained that offshore members were generally confident that they would have the chance to acquire higher level tasks and progress in their careers in the near future. In the other departments (AUTOCONTROL and CORP-TAX), offshore respondents explained that plans for the future distribution of tasks and managerial responsibilities was not entirely clear, and onshore counterparts had not moved advanced tasks to the offshore unit to the degree that they (the offshore members) had hoped for. This situation led to poor career expectations at the offshore unit, contributing to low task effort and employee retention levels:

'A few people have lost their track now ... in terms of their career. They've lost interest because there's not much growth now. People [onshore] are a little reluctant to send work and there were no promotions actually in the last year... So that's the reason people [offshore] get more frustrated and they don't give their best towards the work.' (Offshore respondent in CORP-TAX)

'I think we have lost quite a bit of talented people because there is no scope for growth.' (Offshore respondent in CORP-TAX)

Such drops in motivation and retention levels, in turn, inhibited the development of the higher level competences that were required to perform well on more advanced tasks (see Figure 2, arrows indicating influence of career expectations offshore on task effort and retention, and eventually on task performance).

\subsubsection{Task ownership}

Our data suggest that the actual transfer of advanced tasks to the offshore units had an important effect on offshore employees' task ownership and, through this, on their intrinsic work motivation. In the departments where offshore members felt that their onshore colleagues were putting the offshoring strategy into practice to a full extent, offshore members were seen to be more satisfied and proud to be given these tasks. 
Reportedly, this contributed to higher retention rates, as well as greater effort on the tasks and better performance. Conversely, in the departments whose members felt they were not given sufficiently advanced tasks, offshore members' feeling of task ownership and effort was seen to drop:

... The person ... who is feeling that ownership, he may not feel that good because, in one way, he's trying to prove and execute the task, but .... when he contacts the [onshore] counterpart, he may not get the feel that he's going to be the owner of that task from next time.' (offshore respondent in AUTOCONTROL)

\section{Interdependencies between offshoring strategy and onshore/offshore motivational drivers: The offshoring system}

From our analysis so far, we can infer certain bilateral and trilateral interdependencies between three elements - the offshoring strategy, motivational drivers amongst onshore employees and motivational drivers amongst offshore employees - thus, constituting a system. In the analysis below we point out the bilateral interdependencies between the system's elements, followed by a synopsis of their trilateral interdependencies. We further highlight how the interdependencies led to certain interlocking positive feedback loops. These interdependences and feedback loops are articulated in four propositions, and illustrated in Figure 3.

Insert Figure 3 about here

\subsection{Bilateral interdependencies between system elements}

5.1.1. Interdependencies between offshoring strategy and onshore motivational drivers

We can discern certain bilateral interdependencies between the offshoring strategy, the onshore motivational drivers and the offshore motivational drivers. Our findings suggest that an advanced task offshoring strategy could only be implemented to the degree that onshore managers were motivated to transfer advanced tasks in line 
with the strategy and onshore non-managerial employees were motivated to support the transfer. Moreover, our comparison between the departments showed differences between the departments' strategies with regard to their levels of advanced task offshoring. In each firm, one department was planning to offshore or was already offshoring higher level tasks compared to the other department (see Table 2). For example, AUTOCONTROL in ELECTRO was planning to offshore full financial responsibility and EXPAT-TAX in PROFSERVICE was in the process of offshoring the final review and sign-off of tax computations. These comparisons suggest that the development of a department's strategy depended on the degree to which advanced task offshoring had been implemented through actual task transfer in the past, and this depended of course on the motivational drivers amongst onshore employees. In this sense, the further development of a department's offshoring strategy depended on the motivational drivers amongst onshore employees (see Figure 3, arrow indicating influence of motivation onshore on offshoring strategy via 'Actual task transfer'). We also obtained some indication that middle managers had a direct input into the departmental strategy, as one respondent explained how senior management developed the departmental strategy in consultation with middle managers, who contributed their estimations of workloads and costs. Such cost estimations were of course a function of middle managers' expectations regarding performance and workload.

At the same time, onshore motivational drivers depended on aspects of the strategy itself. Firstly, onshore members' expectations of performance and workload outcomes depended on the degree to which they perceived the organization's offshoring strategy to be 'realistic' in terms of the match between the tasks to be transferred and concurrent skills of offshore members (see Figure 3, arrow indicating influence of offshoring strategy on motivation onshore, via 'task-skill match'). Furthermore, onshore members' career expectations were shaped by the offshoring strategy, which defined what tasks and responsibilities should remain at the onshore units in the future (see Figure 3, arrow indicating influence of offshoring strategy on motivation onshore, via 'future onshore tasks'). The following proposition captures these interdependencies: 
Proposition 1: The implementation and further development of an advanced task offshoring strategy depend on motivational drivers (outcome expectations about performance, careers, and workload) in the onshore units. These motivational drivers in turn depend on aspects of the offshoring strategy (match between tasks to be offshored and offshore skills, plans for future onshore tasks and responsibilities). (see Figure 3a)

Insert Figures 3a to 3e about here

5.1.2. Interdependencies between offshoring strategy and offshore motivational drivers

A second interdependence can be seen between the offshoring strategy and the offshore motivational drivers. The offshoring strategy defined the degree to which advanced tasks and managerial responsibilities were to be offshored in the future, thereby shaping offshore members' task ownership and career expectations (see Figure 3, arrow indicating influence of offshoring strategy on motivation offshore, via 'future offshore tasks'). As described before, these motivational drivers fed into the retention levels and task effort, both of which influenced task performance in the offshore units. This performance in turn determined whether the offshoring strategy could succeed in practice (see Figure 3, arrow indicating influence of motivation offshore on offshoring strategy via 'Performance'). What is more, as offshore units performed better over time, ELECTRO and PROFSERVICE were able to allocate even more advanced tasks to their respective offshore units. A positive feedback loop was thus created (see Figure 3, feedback loop 1), which fed into upward or downward spirals. More specifically, if the strategy of transferring increasingly advanced tasks led to good offshore performance, the strategy could be developed further to allocate yet more advanced tasks to the offshore unit, which enhanced motivation levels in the offshore unit, and this again led to improved performance, and a continuation of the feedback loop at a higher level. The reverse, downward spiral was created when offshore members did not receive increasingly challenging 
tasks and did not see attractive career prospects, which dampened their motivation, leading to poorer performance and success of the offshoring strategy.

Proposition 2: The success and further development of an advanced task offshoring strategy depends on motivational drivers (outcome expectations about careers, and task ownership) for task effort and retention in the offshore units. These motivational drivers depend in turn on aspects of the offshoring strategy (plans for future offshore tasks and responsibilities). This mutual dependency between offshoring strategy and offshore motivational drivers creates a positive feedback loop between these two system elements. (see Figure 3b)

\subsubsection{Interdependencies between onshore and offshore motivational drivers}

We can see that the onshore and offshore motivational drivers were also closely connected. Onshore members' outcome expectations affected the degree to which they transferred tasks to their offshore counterparts, and this in turn influenced offshore members' career expectations and task ownership (see Figure 3, arrow indicating influence of motivation onshore on motivation offshore via 'actual task transfer'). As outlined above, offshore motivational drivers were important for employee retention, task effort, and thereby performance. Notably, actual task transfer also fed into offshore performance simply by providing an opportunity for offshore employees to gain experience and thereby develop the competence to perform advanced tasks. Offshore task performance, in turn, was a crucial determinant of onshore members' expectations about performance and workload, which again fed into their motivation to transfer more advanced tasks to their offshore counterparts, once more stimulating offshore motivation and performance (see Figure 3, arrow indicating influence of motivation offshore on motivation onshore via 'performance').

It follows that the motivation levels in the onshore and offshore units reinforced each other, and that through this interdependence another positive feedback loop was created (see Figure 3, arrows indicating influence of motivation offshore on motivation onshore and vice versa; and feedback loop 2). The following account highlights the mutual influences between task ownership, effort, performance and task transfer: 
'It can also be a kind of hen-and-egg problem.... Are they [offshore members] frustrated because we [onshore members] do not give them interesting tasks and do they not make an effort because of that, or ... do we not trust that they can do it? So what was there first? ... The Indian colleague who you saw this morning had an interest and got involved in it. And because he got involved ... we gave him such things, and supported him.'

Proposition 3: Offshore motivational drivers for task effort and retention are affected by onshore motivational drivers for actual task transfer. Onshore motivational drivers in turn are affected by offshore task performance, which depends on offshore motivation for task effort and retention. This mutual dependency between onshore and offshore motivational drivers creates a positive feedback loop between the two system elements. (see Figure 3c)

\subsection{Trilateral interdependencies between the system elements}

If we take a broader perspective, we can discern a circular interdependence between all three elements: offshoring strategy, motivational drivers onshore, and motivational drivers offshore. When looking at Figure 3 , it is evident that the three system elements form a circular chain of influence that affects offshore performance and thereby the success and further development of an offshoring strategy. This chain reached from the advanced task offshoring strategy over motivational drivers onshore and motivational drivers offshore back to the advanced task offshoring strategy, thereby creating a positive feedback loop (see Figure 3, inner arrows, and feedback loop 3). If we consider the chain of influence in the other direction, we can observe a circular dynamic which is opposite - but not contradictory - to the one just described: The offshoring strategy influenced offshore motivational drivers, which affected offshore members' performance, feeding into onshore motivational drivers and thereby the degree to which onshore members put the strategy into practice (see Figure 3, outer arrows, and feedback loop 4).

We can infer that particularly strong positive feedback loops are created if the three elements of the system accord which one another. If an offshoring strategy is 
not only realistic, but also satisfies both onshore and offshore outcome expectations and offshore task ownership, it is likely to lead to strong motivation onshore as well as offshore, which both feed into performance. This performance will allow for the offshoring strategy to succeed, which is likely to reinforce the motivational drivers onshore and offshore, leading to a continuation of the positive feedback loops (see Figure 3, feedback loops 3 and 4). In this sense, the two feedback loops (3 and 4) reinforce each other and are thus interlocked. If the feedback loops point in the same direction, i.e. support either a further development or a decline in each element, then an overall spiral will emerge, causing the offshoring system to grow or decline, respectively. If they do not point in the same direction, the overall dynamic can be upwards or downwards, depending on which feedback loop is stronger. Overall, we can infer that each element of the offshoring system depends crucially on its interaction with the other elements. The more the three elements of the system accord with each other, the better the offshoring strategy can be implemented and developed to a higher level over time. On the basis of these reflections, we develop the following proposition.

Proposition 4: The interdependencies between the three system elements offshoring strategy, motivational drivers onshore, and motivational drivers offshore yield two interlocking, positive feedback loops. Depending on their cumulative (upwards or downwards) directions, these feedback loops can create an upward or downward spiral (i.e. growth or decline) of the offshoring system. (see Figures $3 d$ and 3e)

\section{Dynamic behavior of the offshoring system - an extrapolation}

A systems analysis of advanced task offshoring would not be complete without reflecting on the dynamic behaviour of the offshoring system, and the external factors that impinge upon these dynamics. Our respondents highlighted two external factors which they felt created constraints for advanced task offshoring: (1) the level of expertise that offshore members could attain and (2) the current demand for a product or service from the client. In both firms, respondents explained that it was not feasible for offshore members to regularly visit clients located closer to the 
onshore units. Compared to their onshore colleagues, offshore members therefore found it harder to develop a deep understanding of client requirements. ELECTRO respondents believed that for this reason, new function development and the client interface (see Table 2) could not be offshored in a majority of the cases, since most of their client firms were headquartered outside the Asian subcontinent. They also believed that there was a limit to the technical expertise that offshore members could acquire within India, due to their restricted exposure to the machineries of advanced automobile systems:

‘... many people who would take over some of the technical modules with respect to some car ... might not know even how to drive a car. ... So that would not have given them exposure to many systems ... So that of course makes a big difference in understanding....' (Offshore respondent in AUTOCONTROL)

Such automotive expertise was, however, regarded as crucial for successfully undertaking highly complex and non-routine tasks. Similarly, respondents in PROFSERVICE felt that the most advanced advisory tasks, new services development, and client acquisition could not be offshored, because these tasks required closer interactions with the client firms, which was hard to arrange for employees located in India. Since they could not attain expertise beyond a point, offshore members' career progression was seen to have a ceiling. At the same time, these limitations to the attainable expertise on the offshore side reassured onshore colleagues that the most advanced tasks would continue to remain onshore and that their own career prospects were secure.

A second crucial external factor restraining advanced task transfer was the demand for a product or service from the client, which determined the amount and the nature of tasks available for onshore employees. When the client demand for new products or services was high, this yielded new, alternative tasks for onshore members to substitute for tasks that were offshored. For example in PROFSERVICE, high demand by clients in London had created a task overload for onshore employees, which strongly motivated them to offshore tasks, in contrast to the low demand by clients and low offshoring motivation in the other UK regions:

'...business down here was quite buoyant so everyone who was employed here was able to stay busy, but they didn't have the resource to do the work onshore so it had to be done in Bangalore. And when a team is in that position they certainly 
make it work ... So we found ... that the London relationship was going significantly better than some others and it had a lot to do with the fact that there was nobody onshore worried about their job. ...' (Onshore respondent in CORP-TAX).

By contrast, lower client demand restricted the amount of available tasks. In this situation, onshore members were more concerned about their career prospects and therefore more hesitant to move advanced tasks offshore:

'You ask yourself: "What are we going to do over here, if we transfer everything to India?"' (Onshore respondent in AUTOCONTROL)

From a systems perspective, these two external factors (attainable offshore expertise and client demand) can be described as 'resources' that determine the 'carrying capacity' of the offshoring system. The notion of carrying capacity has its roots in ecological studies and has been applied to organizational contexts by dynamic systems theorists. According to Sterman (2000: 118), 'the carrying capacity of any habitat is the number of organisms of a particular type that it can support and is determined by the resources available in the environment and the resource requirements of the population'.

The external factors outlined by our respondents (i.e. the expertise attainable for offshore members and the demand from the client) can be viewed as key resources underpinning the offshoring system, which create an upper limit to the system's growth. Even when all elements of the system are in line with each other, leading to upward spirals, growth is still likely to level off when the system reaches the limits of its resources. Hence, when advanced task offshoring reaches a level where the offshore unit's expertise is not enough to take on yet more advanced tasks, and/or low demand from the client constrains the number of alternative tasks for onshore members, then negative feedback loops are likely to emerge, which selfcorrect and counteract the preceding change. At this stage, the system may reach its carrying capacity. Onshore members are likely to lose motivation to transfer yet more advanced tasks, and the growth of the system could level off.

Depending on the severity of the shortage of resources (i.e. attainable expertise and client demand), there may be a point where the negative feedback loops lead to a reverse, downwards spiral of the system dynamics, and a decline of the system (see Sterman 2000: 123). To continue with our reasoning: When stagnating career prospects lead to a demotivation of offshore members and thereby 
poor performance, this will entail lower expectations of performance and less motivation to transfer tasks on the side of onshore members. Similarly, a severe lack of new, alternative tasks can threaten onshore career prospects to the extent that onshore members are strongly demotivated to transfer advanced tasks, feeding into the downward spiral. If these dynamics are particularly strong, this can stop advanced task offshoring and may even trigger 're-shoring' (see Booth 2013).

We have to take into account, however, that a system's carrying capacity can change with the system's environment (Sterman 2000: 123). We argue that the offshoring system's carrying capacity will change with the rising levels of expertise that offshore members can attain, and the fluctuating demand from clients. Firstly, as global firms are increasingly turning to offshore destinations for innovation, research and development (R\&D) work (see Dossani and Kenney 2007; Fernandez-Stark et al. 2011; Lewin et al. 2009), offshore units are getting more opportunities for closer interactions and better exposure to clients. Also, steps are being taken in offshoring hotspots such as India to train college students - many of whom will eventually work for offshore units of global firms - on cutting edge technologies, products and processes (see Fernandez-Stark et al. 2011; Wadhwa et al. 2008). As the levels of expertise available in offshore units increase, firms can take advanced task offshoring to higher levels, which fosters career expectations of offshore members and feeds into an upward spiral as explained in our model (see Figure 3). At the same time, however, these rising levels of expertise are likely to intensify onshore members' insecurities about their own career prospects (particularly in times of economic uncertainty), which feeds into the downward spiral of the system (see Figure 3). Secondly, fluctuations in the firm's economic environment will affect the client demand. Our respondents illustrated this by recounting the immediate aftermath of the economic crisis of 2008, when fewer projects were acquired, and onshore members had therefore been less willing to offshore advanced tasks. In short, changes to the two external factors - attainable expertise in the offshore unit and demand from the client - need to be considered in tandem in order to understand their overall effect on the development of the system.

Onshore and offshore career expectations are the two system components that may have a tendency to disaccord with each other, because the transfer of tasks from onshore to offshore members is likely to create tensions between onshore and 
offshore career interests. We would argue that such tensions are particularly amplified in the case of advanced task offshoring, where career prospects have to meet the expectations of highly qualified onshore as well as offshore employees, and the two groups of employees are intensely competing with one another for obtaining increasingly advanced tasks. Given that they are interrelated and at the same time contradictory, onshore and offshore career expectations are likely to constitute a paradox within the system (see Smith and Lewis 2011: 382). If an offshoring strategy favors onshore careers at the expense of offshore career prospects, or vice versa, the paradox of the onshore and offshore motivational drivers is likely to persist. In order to achieve a temporary equilibrium of the offshoring system and thus allow for its growth, senior managers thus have to master the difficult job of designing offshoring strategies which respond to these competing demands simultaneously.

\section{Discussion}

\subsection{Theoretical contributions}

To our knowledge, this paper is the first to examine the interdependencies between offshoring strategies and micro level motivational drivers amongst onshore and offshore employees. By using a systems perspective, we were able to demonstrate how these elements act as part of an offshoring system. We have described how the bilateral and trilateral interdependencies between an offshoring strategy, onshore motivational drivers, and offshore motivational drivers yield several self-reinforcing positive feedback loops which create and perpetuate the offshoring system. We further proposed how the system is likely to develop and behave within the external constraints set by the attainable expertise for offshore employees, and by client demands. Our systems analysis suggests that a change in any one of the system elements will cause the others to change, resulting in different levels of implementation and success of the offshoring strategy. This makes it apparent how limiting it is to view either the offshoring strategy or micro level motivational drivers as self-contained units of analysis, if the aim is to understand offshoring implementation or success. 
This view agrees of course with the notion of emergent strategy (e.g. Mintzberg, 1978; Mirabeau \& Maguire, 2014), which posits that organisational strategy emerges through an iterative process of strategy formulation and implementation, and is affected by various social processes within a firm. Strategy development is thus not a step that can be fully separated from its implementation the two are closely intertwined. Similarly, we have demonstrated iterations between strategy implementation and further development, and how both are affected by motivational drivers. Our findings additionally imply that the iterative process of strategy implementation and development can take the form of upward and downward spirals, which are perpetuated by the recursive influence between strategy and motivational drivers.

In parts, our model consolidates Bidwell's (2010; 2012) prior evidence that the implementation of an offshoring strategy follows local rationales rather than firm level rationales. Whilst Bidwell's research shows that offshoring decisions depend on the local rationales of unit mangers, we additionally highlight that the implementation of a departmental offshoring strategy depends on the rationales (in terms of outcome expectations) of the department's managerial as well as non-managerial employees. We further demonstrate that the success and further development of the offshoring strategy depends not just on onshore but also on offshore rationales, namely offshore employees' outcome expectations and task ownership. Our study adds to Bidwell's (2010; 2012) research by demonstrating how local rationales could, in turn, depend on the offshoring strategy, and impinge back upon the implementation, success, and further development of an advanced tasks' offshoring strategy.

Our findings also provide an interesting new slant on some of Manning's (2014) findings. As mentioned earlier, Manning found that a change in a firm's offshoring strategy in terms of a relocation of operations occurred almost exclusively in response to external challenges but not internal challenges. He argued that firms which follow multiple strategic objectives beyond cost savings, such as service quality and client satisfaction (like the firms in our study) tend to react to internal challenges such as employee resistance and offshore employee turnover by mitigation rather than tolerance. Mitigation practices could include, for example, investments into face to face meetings or intercultural training. Our findings add the observation that onshore resistance and offshore employee turnover can also be 
mitigated by a modification of the offshoring strategy, for example by an allocation of more attractive tasks to onshore as well as offshore units, and a more explicit future distribution of tasks to onshore and offshore units.

This paper also goes beyond prior offshoring studies on employee level processes linked to motivational drivers (e.g. Cohen and El Sawad 2007; Mattarelli and Tagliaventi 2012; Metiu 2006; Zimmermann and Ravishankar 2014). Whilst most of these prior studies focus on the importance of onshore employee level processes, we have also highlighted how onshore motivation affected and interacted with relevant offshore motivational drivers, and with the offshoring strategy. Furthermore, these prior employee level studies have concentrated on particular socio-political dynamics between onshore and offshore members, such as status closure (Metiu 2006), post-colonial power re-negotiations (Mahadevan 2011; Ravishankar et al. 2010) and uncertainties about the social order (Cohen and El Sawad 2007). By contrast, we have identified more fundamental drivers of behavior, namely outcome expectations and task ownership, which can be triggered by various factors beyond socio-political dynamics, including aspects of the advanced tasks' offshoring strategy itself. This allowed us to extend the social perspective on motivational drivers and throw light on their systemic interdependence with the offshoring strategy.

\subsection{Managerial relevance}

Our findings send clear messages to managers who have to design a strategy for advanced task offshoring. Whilst this offshoring strategy does of course have to satisfy firm- and department level calculations of benefits and costs, it equally has to consider micro level motivational drivers. Firstly, onshore members' estimations of feasibility have to be taken into account. If onshore members do not believe that the tasks to be transferred at a given point in time match offshore members' concurrent skill levels, the strategy is less likely to be implemented successfully. Sufficient time and capacity has to be allocated for recruitment, training, and continuous support of offshore members until the required skill levels are reached. For offshore employees, this could help avoid the 'catch 22' of not receiving challenging tasks without sufficient task experience, whilst not being able to obtain that experience without working on such tasks. 
An allocation of tasks that is perceived to be realistic (i.e. achieving an alignment between offshored tasks and skills in the offshore unit) has more potential to trigger an upward rather than a downward spiral of offshore performance, onshore outcome expectations, and actual task transfer. However, such realistic task allocation has to be balanced with the need to provide good career prospects for onshore as well as offshore members. Even if a strategy is realistic in terms of the task-skill match, onshore members may still not support it if they feel that it endangers their own jobs and careers. However, if managers set the ceiling for advanced task transfer too low, members of offshore units may not see sufficiently challenging career prospects. They may therefore lose motivation or/and leave the firm, which can trigger a negative spiral endangering the implementation and success of the offshoring strategy. As mentioned before this is likely to be an issue particularly in the case of advanced task offshoring, where career prospects have to meet the expectations of highly qualified onshore as well as offshore employees. Our study suggests that the problem of the career ceiling for offshore members may become even greater when advanced task offshoring reaches a mature level, because there seems to be a 'natural', industry specific ceiling to offshoring, enforced by the location of client firms. This ceiling may however be rising, given the increasing industrial development of emerging economies.

In order to avoid the negative spirals and yield positive ones, senior managers thus need to take both a performance perspective and a career perspective, i.e. they have to design a strategy that is both realistic and fulfils onshore-offshore career expectations. To harmonize onshore and offshore career aspirations simultaneously is of course very difficult and their paradox may persist. One solution may be to offer what one of the offshore managers in our study called a 'combined career pyramid' for onshore and offshore members. Managers can provide attractive career paths for offshore colleagues only as long as this does not jeopardize onshore members' career expectations, and vice versa, because both feed into the implementation of the offshoring strategy.

\subsection{Limitations and directions for future research}


Given that the model developed in this paper examines some very fundamental motivational drivers, we expect it to be transferable to at least a few other sectors and contexts. However, the model may have to be modified to account for different settings. For example, other service sectors are likely to follow different task allocation strategies and may have other limitations for offshoring. We have explained that the match between offshored tasks and skills depends on the available expertise at the offshore destination, and available opportunities for offshore members to interact with clients. We have demonstrated this with regard to IT for automotive electronics and tax services, but the availability of skills and access to clients may be different in other sectors, such as legal and insurance services. By studying a different range of sectors, future research could therefore define more general task characteristics and contextual factors that affect the implementation and success of an offshoring strategy.

Future studies could also inquire whether our model applies only to advanced task offshoring, and the extent to which it is transferable to the offshoring of simple, routine tasks that do not require high levels of expertise. In the case where offshore units are responsible exclusively for routine tasks whilst advanced tasks stay onshore, onshore and offshore employees are likely to have different qualifications and career aspirations, and it may therefore be easier to harmonize onshore and offshore career expectations. Moreover, when routine tasks are offshored, presumably, less experience will be required to perform the task well. Task performance will therefore be less sensitive to employee turnover rates, and onshore employees may develop more positive performance and workload expectations.

Our empirical data was collected in captive offshoring settings. In this context the effect of an offshoring strategy on offshore motivational drivers may be stronger than in the case of outsourcing to external vendors. In captive offshoring, the future of offshore tasks is fully determined by the offshoring strategy and actual task transfer within a firm. In the classic outsourcing setting however, third-party offshore vendors can receive attractive tasks from other clients, and the impact of one client's offshoring strategy and task transfer may not fully determine offshore career expectations and task ownership. Future research could thus set up comparative case studies to examine how the interdependence between strategy and motivational drivers differs between captive and non-captive offshoring settings. 
There may also be more interdependencies between the systems elements than we were able to uncover. ${ }^{3}$ For example, if onshore employees have very low expectations of their offshore colleagues' performance, they may not come to fear for their own tasks and jobs, no matter how transparent (or not) the offshoring strategy is with regard to future onshore and offshore tasks. In this sense, one motivational driver could override another, weakening the interdependencies between the offshoring strategy and a particular set of motivational drivers.

Further, there are certain aspects of motivational drivers in offshoring that remain to be explored. ${ }^{4}$ By framing motivational drivers as outcome expectations and task ownership, our respondents reported on largely rational motives of actual task transfer, task effort, and retention. For example, job loss and task ownership can be regarded as rational motives based on self-interest. Whilst this focus reflects our respondents' emphasis, there were also some signs that outcome expectations can be based on non-rational processes. For example, a few respondents indicated that in some cases, onshore employees' fears of task loss and additional workload may have biased their judgment and had led them to view any mistake by offshore employees as a 'capability' issue.

From a theoretical viewpoint, additional cognitive biases are likely. For example, social identity theory (SIT) suggests that people judge members of outgroups - such as other national groups and subsidiaries - less favourably than members of their in-group (e.g. Tajfel, 1982). This may have biased some onshore employees' judgements of their offshore colleagues' performance. Moreover, SIT research shows that people generally prefer to interact with members of their ingroup rather than outgroup. This effect may bias onshore employees' outcome expectations regarding the effort it takes to coordinate work with offshore units. In addition, prospect theory (Tversky \& Kahneman, 1986) suggests that onshore and offshore employees' negative outcome expectations may have overridden their positive outcome expectations (at least in some cases), if we assume that the avoidance of possible losses - such as job losses - is a more powerful motivator than hoped for gains.

\footnotetext{
${ }^{3}$ We thank anonymous reviewer R3 for this insight.

${ }^{4}$ We are grateful to our anonymous reviewer R3 for the helpful and insightful suggestions which led to the development of the following three paragraphs.
} 
Future research could also draw on agency theory (e.g. Jensen \& Meckling, 1976) to explore how employees' expectations of outcomes that offshoring has for themselves can bias their judgement of organizational level outcomes. In the case that the expected outcomes are beneficial for the firm but detrimental for any given employee or group of employees, these employees may rationalize and downplay the chances or degree of positive firm outcomes. Alternatively, employees may then simply prioritize their personal well-being and act accordingly (e.g. withhold tasks onshore), even if they fully accept that a different action (offshoring these tasks) would be best for the firm. Both options suggest that tensions between outcomes for the firm and for employees are likely to impede offshoring success. At the same time, our study suggests that there may be a 'sweet spot', namely a point where offshore employees' career prospects and their performance is strong, but not strong enough to threaten onshore tasks or jobs, and, similarly, a point where the actual capability of offshore employees is high, but not so high that the firms consistently lose their best offshore employees to rivals. When this balance is achieved, the offshoring goals of the organization, such as maximizing actual task transfer and motivating and retaining talented offshore employees, may indeed be congruent with desirable outcomes for onshore and offshore employees.

\section{REFERENCES}

Bandura, A. (1997). Self-Efficacy: The exercise of control. New York: W.H. Freeman.

Bidwell, M. (2010). Problems deciding: How the structure of make-or-buy

decisions leads to transaction misalignment, Organization Science, 21(2), 362-379.

Bidwell, M. (2012). Politics and firm boundaries: How organizational structure, group interests, and resources affect outsourcing. Organization Science, 23(6),1622-1642.

Booth, T. (2013). Here, there and everywhere: Special report on outsourcing and 
offshoring.

http://www.economist.com/sites/default/files/20130119 offshoring davos.pdf. Accessed 7 January, 2015.

Bunyaratavej, K., Hahn, E.D., \& Doh, J.P. (2007). International offshoring of services: A parity study. Journal of International Management, 13(1), 7-21.

Ceci, F., \& Prencipe, A. (2013). Does distance hinder coordination? Identifying and bridging boundaries of offshored work. Journal of International Management, 19(4), 324-332.

Clampit, J., Kedia, B. Fabian, F., \& Gaffnery, N. (2015). Offshoring satisfaction: The role of partnership credibility and cultural complementarity. Journal of World Business, 50(1), 79-93.

Cohen, L. \& El-Sawad, A. (2007). Lived experiences of offshoring: An examination of UK and Indian financial service members' accounts of themselves and one another. Human Relations, 60(8), 1235-1262.

Contractor, F.J., Kumar, V., Kundu, S.K., \& Pedersen, T. (2010).

Reconceptualizing the firm in a world of outsourcing and offshoring: The organizational and geographical relocation of high-value company functions. Journal of Management Studies, 47(8), 1417-1433.

Corley, K.G. \& Gioia, D.A. (2004). Identity ambiguity and change in the wake of a corporate spin-off. Administrative Science Quarterly, 49(2), 173-208.

Cyert, R. M. \& March, J. G. (1963). A behavioral theory of the firm. Engelwoods Cliffs, NJ: Prentice Hall.

Demirbag, M., Mellahi, S., Sahadev, K., \& Elliston, J. (2012). Employee service abandonment in service operations: Acase study of a US multinational in India. Journal of World Business, 47(2), 178-185.

Dibbern, J., Winkler, J., \& Heinzl, A. (2008). Explaining variations in client extra costs between software projects offshored to India. MIS Quarterly, 32(2), 333366.

Dossani, R., \& Kenney, M. (2007). The next wave of globalization: relocating service provision to India. World Development, 35(5), 772-791.

Eisenhardt, K. (1989). Building theories from case study research. Academy of Management Review, 14(4), 532-550.

Fernandez-Stark, K., Bamber, P., \& Gereffi, G. (2011). The offshore services 
global value chain: Economic upgrading and workforce development. A Centre on Globalization, Governance and Competitiveness (CGGC) Report, Duke University. http://www.cggc.duke.edu/pdfs/2011-1111 CGGC Offshore-Services-Global-Value-Chain.pdf. Accessed 7 January, 2015.

Geertz, C. (1973). The Interpretation of Cultures. New York: Basic Books.

Gerbl, M., Mclvor, R., Loane, S., \& Humphreys, P. (2015). A multi-theory approach to understanding the business process outsourcing decision. Journal of World Business, 50(3), 505-518.

Gopal, A., \& Koka, B. (2012). The asymmetric benefits of relational flexibility: Evidence from software development outsourcing. MIS Quarterly, 36(2), 553576.

Handley, S.M., \& Benton, W.C. (2013). The influence of task- and location-specific complexity on the control and coordination costs in global outsourcing relationships. Journal of Operations Management, 31(3), 109-128.

Jensen, M.C., \& Meckling, W.H. (1976). Theory of the firm: Managerial behavior, agency costs and ownership structure. Journal of Financial Economics, 3(4), 305-360.

Jensen, P.D.O., Møller-Larsen, M., Manning, S., \& Pedersen, T. (2013). The organizational design of offshoring: Taking stock and moving forward. Journal of International Management, 19(4), 315-323

Jensen, P.D.O., \& Pedersen, T. (2012). Offshoring and international competitiveness: antecedents of offshoring advanced tasks. Journal of the Academy of Marketing Science, 40(2), 313-328.

Jensen, P.D.O., \& Petersen, B. (2013). Global sourcing of services: Risk, process, and collaborative architecture. Global Strategy Journal, 3(1), 67-87.

Johnson, G., Melin, L., \& Whittington, R. (2003). Guest editors introduction. Micro strategy and strategizing: Towards an activity-based view. Journal of Management Studies, 40(1), 3-22.

Karmarkar, U. 2004. Will you survive the services revolution? Harvard Business Review, 82(6), 100-106.

Katz, D., \& Kahn, R. (1978). The social psychology of organizations. New York: John Wiley. 
Kedia, B.L., \& Mukherjee, D. (2009). Understanding offshoring: A research framework based on disintegration, location and externalization advantages. Journal of World Business, 44(3), 250-261.

Kotabe, M., Mol, M.J., \& Ketkar, S. (2008). An evolutionary stage model of outsourcing and competence destruction: A Triad comparison of the consumer electronics industry. Management International Review, 48(1), 6593.

Kumar, K., Fenema, P.C., \& von Glinow, M.A. (2009). Offshoring and the global distribution of work: Implications for task interdependence theory and practice. Journal of International Business Studies, 40(4), 642-667.

Lampel, J., \& Bhalla, A. (2011). Living with offshoring: The impact of offshoring on the evolution of organizational configurations. Journal of World Business, 46(3), 346-358.

Lacity, M.C., Iyer, V.V., \& Rudramuniyaiah, P.S. (2008). Turnover intentions of Indian IS professionals. Information Systems Frontiers, 10(2), 225-241.

Lewin, A. Y., \& Couto, V. (2007). Next generation offshoring - The globalization of innovation. Raleigh: Duke University, The Fuqua School of Business.

Lewin, A.Y., Massini, S., \& Peeters, C. (2009). Why are companies offshoring innovation? The emerging global race for talent. Journal of International Business Studies, 40(6), 901-925.

Luo, Y., Wang, S.L., Zheng, Q., \& Jayaraman, V. (2012). Task attributes and process integration in business process offshoring: A perspective of service providers from India and China. Journal of International Business Studies 43(5), 498-524.

Luo, Y., Wang, S.L., Jayaraman, V., \& Zheng, Q. (2013). Governing business process offshoring: Properties, processes, and preferred modes. Journal of World Business, 48 (3) 407-419

Mahadevan, J. (2011). Power/knowledge in postcolonial settings: The case of IT Bangalore. Interculture Journal, 10(13), 61-81.

Manning, S. (2014). Mitigate, tolerate or relocate? Offshoring challenges, strategic imperatives and resource constraints. Journal of World Business, 49(4), 522535.

Manning, S., Møller-Larsen, M., \& Bharati , P. (2015). Global delivery models: The 
role of talent, speed and time zones in the global outsourcing industry. Journal of International Business Studies, 46(7), 850-877.

Mattarelli, W., \& Tagliaventi, M.R. (2012). How offshore professionals' job dissatisfaction can promote further offshoring: Organizational outcomes of job crafting. Journal of Management Studies, Early view, DOI: 10.1111/j.14676486.2012.01088.x

Metiu, A. (2006). Owning the code: status closure in distributed groups. Organization Science, 17(4), 418-435.

Mintzberg, (H. 1978). Patterns in strategy formation. Management Science, 24(9), 934-948.

Mirabeau, L., \& Maguire, S. (2014). From autonomous strategic behaviour to emergent strategy. Strategic Management Journal, 35(8), 1202-1229.

Møller-Larsen, M., Manning, S., \& Pedersen, T. (2013). Uncovering the hidden costs of offshoring: The interplay of complexity, organizational design, and experience. Strategic Management Journal, 34(5), 533-552.

Mudambi, R., \& Venzin, M. (2010). The strategic nexus of offshoring and outsourcing decisions. Journal of Management Studies, 47(8), 1510-1533.

Mukherjee, D., Gaur, A.S., \& Datta, A. (2013). Creating value through offshore outsourcing: An integrative framework. Journal of International Management, 19(4) 377-389.

Murray, J. Y., Kotabe, M. and Westjohn, S. A. (2009). Global sourcing strategy and performance of knowledge-intensive business services: a two-stage strategic fit model'. Journal of International Marketing, 17(4), 90-105.

Ravishankar, M.N., Cohen, L., \& El Sawad, A. (2010). Examining resistance, accommodation and the pursuit of aspiration in the Indian IT-BPO space: Reflections on two case studies. Industrial Relations Journal, 41(2), 154-167.

Rottman, J. W. (2008). Successful knowledge transfer within offshore supplier networks: a case study exploring social capital in strategic alliances. Journal of Information Technology, 23(1), 31-43.

Sartor, M.A., \& Beamish, P.W. (2014). Offshoring innovation to emerging markets: Organizational control and informal institutional distance. Journal of International Business Studies, 45(9), 1072-1095.

Schmeisser, B. (2013). A Systematic review of literature on offshoring of value 
chain activities. Journal of International Management, 19(4), 390-406.

Schmitt, A., \& Van Biesebroeck, J. (2013). Proximity strategies in outsourcing relations: The role of geographical, cultural and relational proximity in the European automotive industry. Journal of International Business Studies, 44(5), 475-503.

Smith, W.K., \& Lewis, M.W. (2011). Toward a theory of paradox: A dynamic equilibrium model of organizing. Academy of Management Review, 36(2), 381-403.

Sterman, J. D. (2000). Business dynamics: Systems thinking and modelling for a complex world. New York: Irwin.

Strauss, A., \& Corbin, J. (1990). Basics of qualitative research. Newbury Park, CA: Sage.

Stringfellow, A. Teagarden, M.B., \& Nie, W. (2008). Invisible costs in offshoring services work. Journal of Operations Management, 26(2),164-179.

Tajfel, H. (1982). Social Psychology of intergroup relations. Annual Review of Psychology, 33(1), 1-39.

Thibodeau, P. (2014). This IT worker had to train an H1B replacement, Computer World. http://www.computerworld.com/article/2490610/it-outsourcing/this-itworker-had-to-train-an-h-1b-replacement.html Accessed Jan 10, 2016.

Thibodeau, P. (2015). Fury and fear as Ohio IT jobs go to India, Computer World. http://www.computerworld.com/article/3002681/it-outsourcing/fury-and-fear-inohio-as-it-jobs-go-to-india.html Accessed Jan 23, 2016.

Tversky, A., \& Kahneman, D. (1986). The behavioural foundations of economic theory. The Journal of Business, 59(4), 251-278.

Wadhwa, V., De Vitton U.K., \& Gereffi, G. (2008). How the disciple became the guru: Is it time for the U.S. to learn workforce development from former disciple India? Durham, N.C.: Duke University and the Kauffman Foundation. http://www.soc.duke.edu/GlobalEngineering/papers disciple.php. Accessed 7 January, 2015.

Yin, R. (2009). Case study research design and methods, 4th Edition, London: Sage. Zimmermann, A., \& Ravishankar, M.N. (2011). Collaborative IT offshoring relationships and professional role identities: Reflections from a field study. Journal of Vocational Behavior, 78(3), 351-360. 
Zimmermann, A., Raab, K., \& Zanotelli, L. (2012). Vicious and virtuous circles of offshoring attitudes and relational behaviours. A configurational study of German IT developers. Information Systems Journal, 23(1), 65-88.

Zimmermann, A., \& Ravishankar, M.N. (2014). Knowledge transfer in IT offshoring relationships: The roles of social capital, efficacy, and outcome expectations. Information Systems Journal, 24(3), 167-202. 
Figure 1 Data structure

First-order concepts

- Plans to offshore new function development and financial liability for Asian clients.

- Plans to offshore advisory work, final reviews, and sign-off

- 'Local for local': Plans to make both onshore and offshore offices fully responsible for their local clients (ELECTRO)

- Offshore unit will stay responsible for new services development, client acquisition, and financial liability (PROFSERVICE)
Theoretical categories

\section{Aggregate theoretical} dimensions

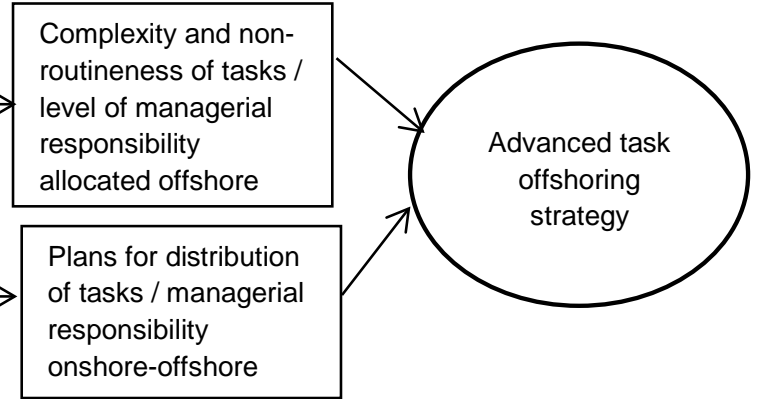

- Onshore employees are more willing to transfer tasks over time because they expect them to be completed well offshore.

- Concerns about 'offshoring our own jobs', 'what will be left for us to do if this task is offshored'.

- Concerns about 'offshoring our own jobs', 'what will be left for us to do if this task is offshored'.

\section{$\rightarrow$}

Expectations about performance

Expectations about workload outcomes

Expectations about career prospects

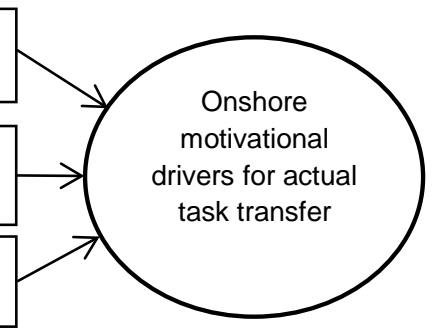

- Offshore employees with better career perspectives are more motivated to stay with the firm and put effort into their task to demonstrate their abilities.
- Offshore employees who are given the responsibility for attractive tasks put more effort into the tasks, and are more likely to stay with the firm in the long run.

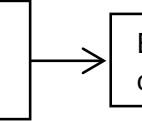

Expectations about career prospects

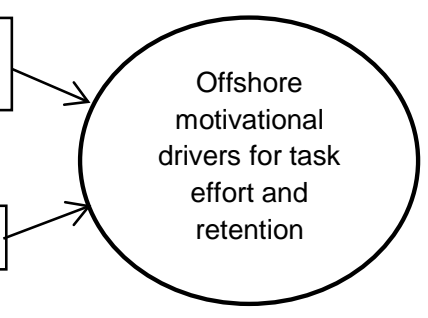

motivationa drivers for task $\rightarrow$ Task ownership

- Onshore employees do not offshore certain tasks because they believe the offshoring strategy is unrealistic.

- Offshore employees who do not see clear plans for future offshoring of higher level tasks feel that it is not worth putting effort into their current tasks. This restricts their performance and the possibility of future offshoring.

- The transfer of advanced tasks fosters offshore employees career expectations and task ownership, which entail better effort, retention, and performance. When onshore employees have witnessed strong offshore performance, they are more motivated to transfer advanced tasks.

\section{Interdependencies between motivational drivers and offshoring strategy}

Interdependencies between motivational drivers onshore and offshore

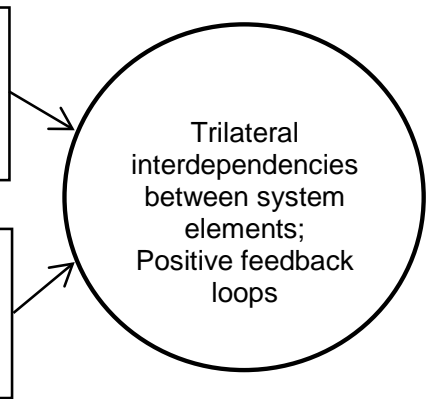

- Offshore employees cannot regularly visit and gain a deep understanding of clients located close to the onshore units.

- Offshore employees are not sufficiently exposed to advanced automotive machinery to gain the highest levels of automotive expertise.

- High client demand for new products yields new, alternative tasks for onshore employees. This improves their career expectations.

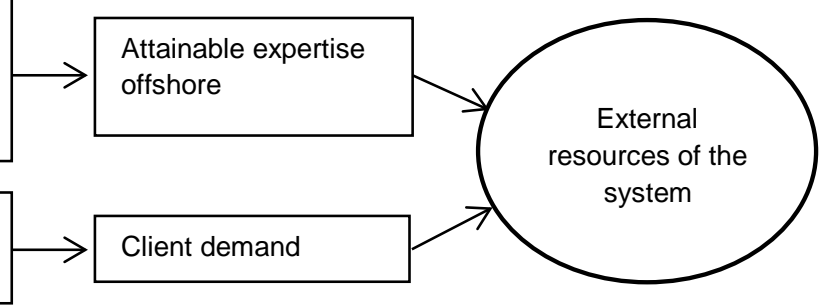


Fig. 2 Grounded model of advanced task offshoring strategy and onshore/offshore motivational drivers

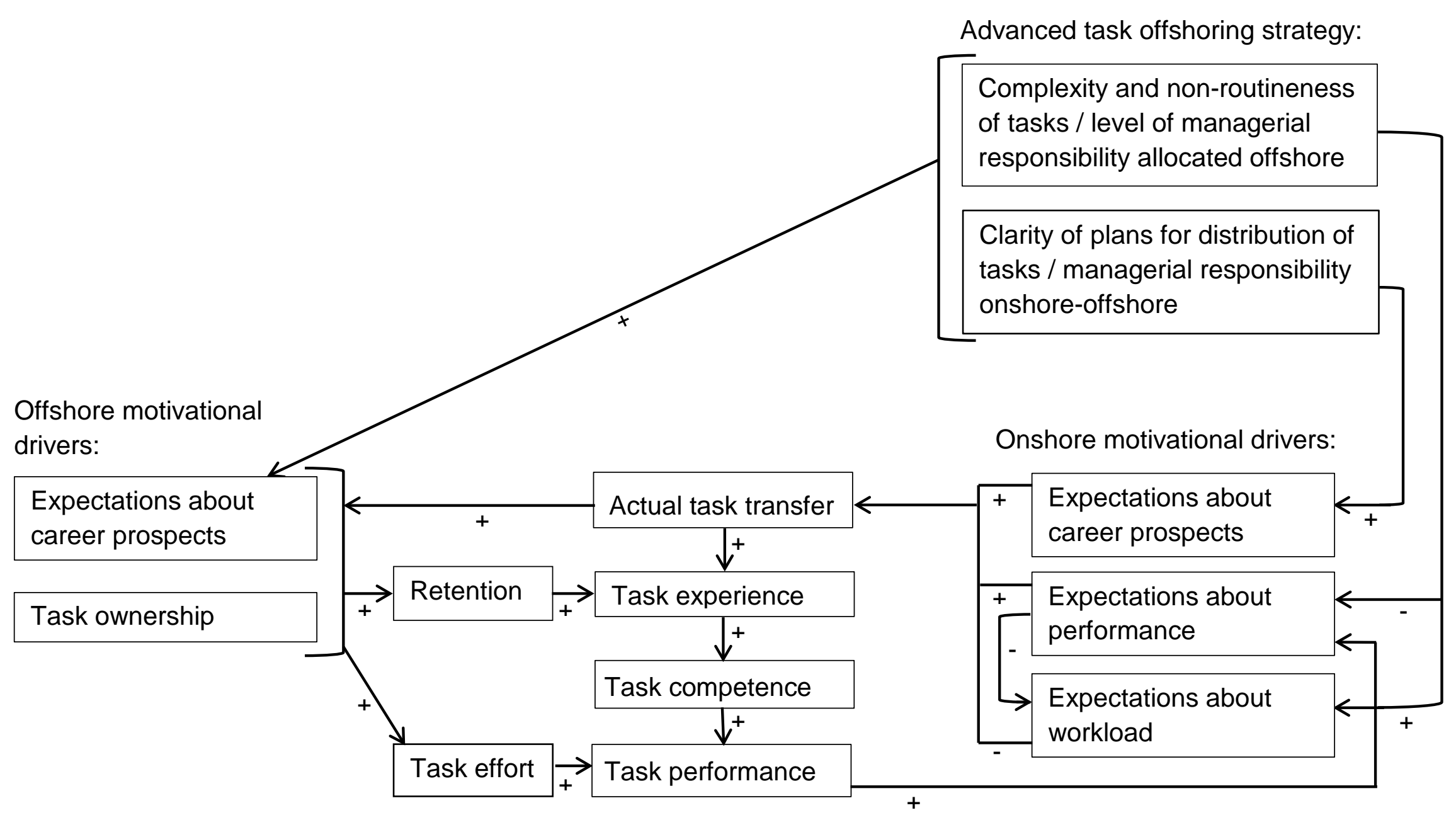




\section{Explanation of relationships depicted in Figure 2}

- Onshore employees' expectations about offshore performance contribute to the actual transfer of advanced tasks. These performance expectations are shaped by onshore employees' (a) experience of offshore performance and (b) perceived match of the complexity and non-routineness of tasks, and of the level of managerial responsibility allocated offshore, with offshore employees' skill levels.

- Onshore employees' expectations about the workload created through advanced task transfer contribute to the actual transfer of advanced tasks. These workload expectations are shaped by onshore employees' (a) expectations regarding offshore performance and (b) perceived match of the complexity and non-routineness of tasks, and of the level of managerial responsibility allocated offshore, with offshore employees' skill levels.

- Onshore employees' expectations about outcomes for their careers contribute to the actual transfer of advanced tasks. These career expectations are shaped by onshore employees' perception of plans for the future allocation of tasks and responsibilities to onshore units.

- Offshore employees' expectations about outcomes for their careers contribute to their level of task effort and retention with the firm, which feed into offshore employees' task performance. Offshore employees' career expectations are affected by (a) their perception of clear plans for the future allocation of tasks and responsibilities to offshore units, and (b) by the actual task transfer.

- Offshore employees' task ownership contributes to offshore employees' level of task effort and retention with the firm, which contribute to their task performance. Offshore employees' task ownership is affected by the actual transfer of advanced tasks. 
Figure 3 Interdependencies between advanced task offshoring strategy, motivational drivers onshore, and motivational drivers offshore

\section{Interdependencies:}

- Offshoring strategy and Motivational drivers onshore

- Offshoring strategy and Motivational drivers offshore

- Motivational drivers onshore and offshore

- Interdependencies between all three elements

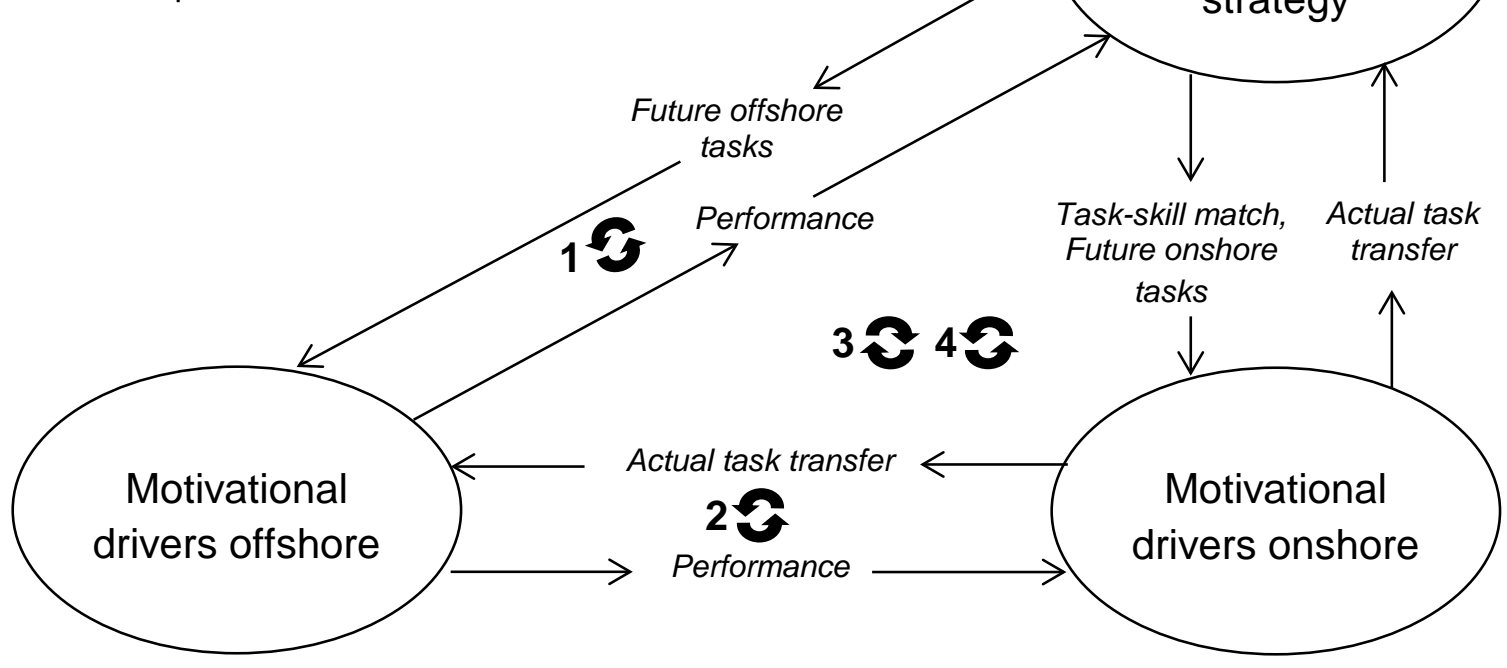


Figures 3a, 3b, 3c and 3d/3e below depict the specific interactions within Figure 3, which contribute to propositions 1, 2, 3 and 4 respectively.

Figure $\mathbf{3 a}$

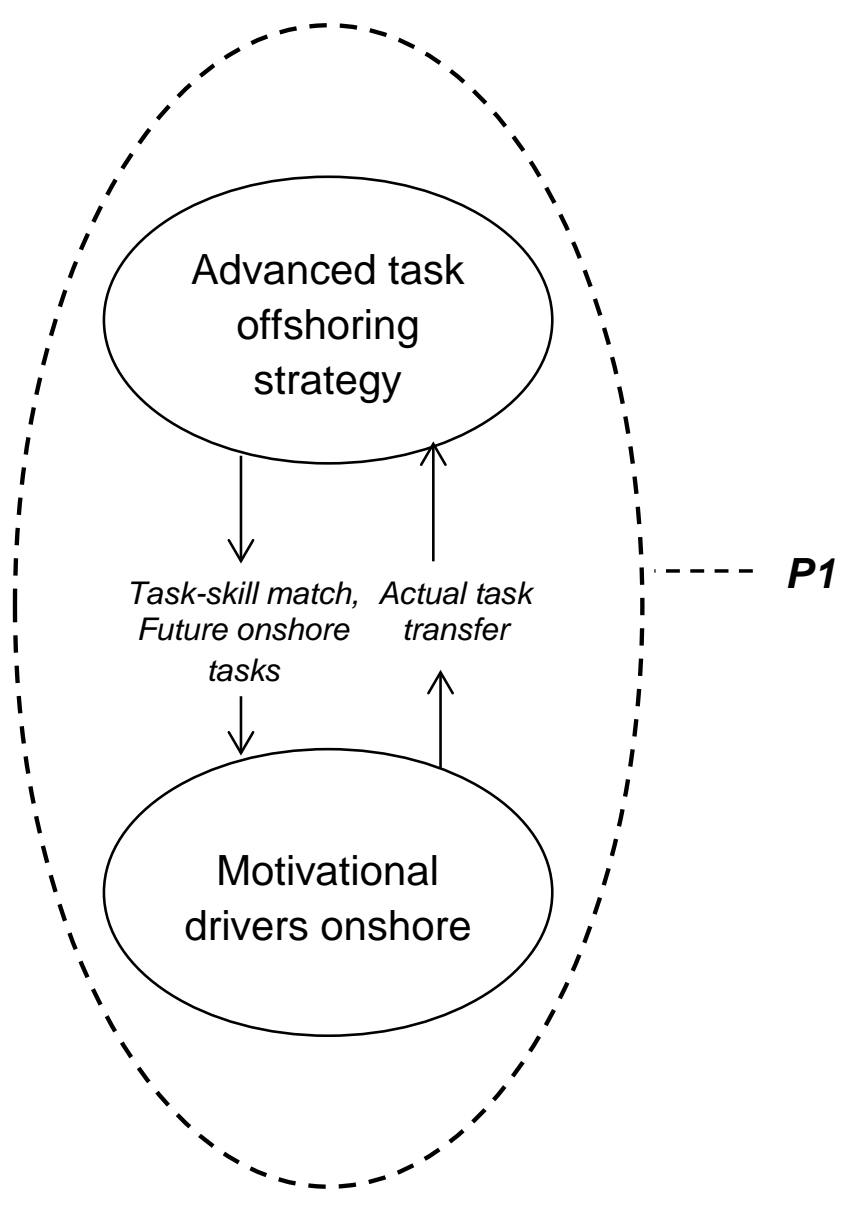




\section{Figure $3 b$}

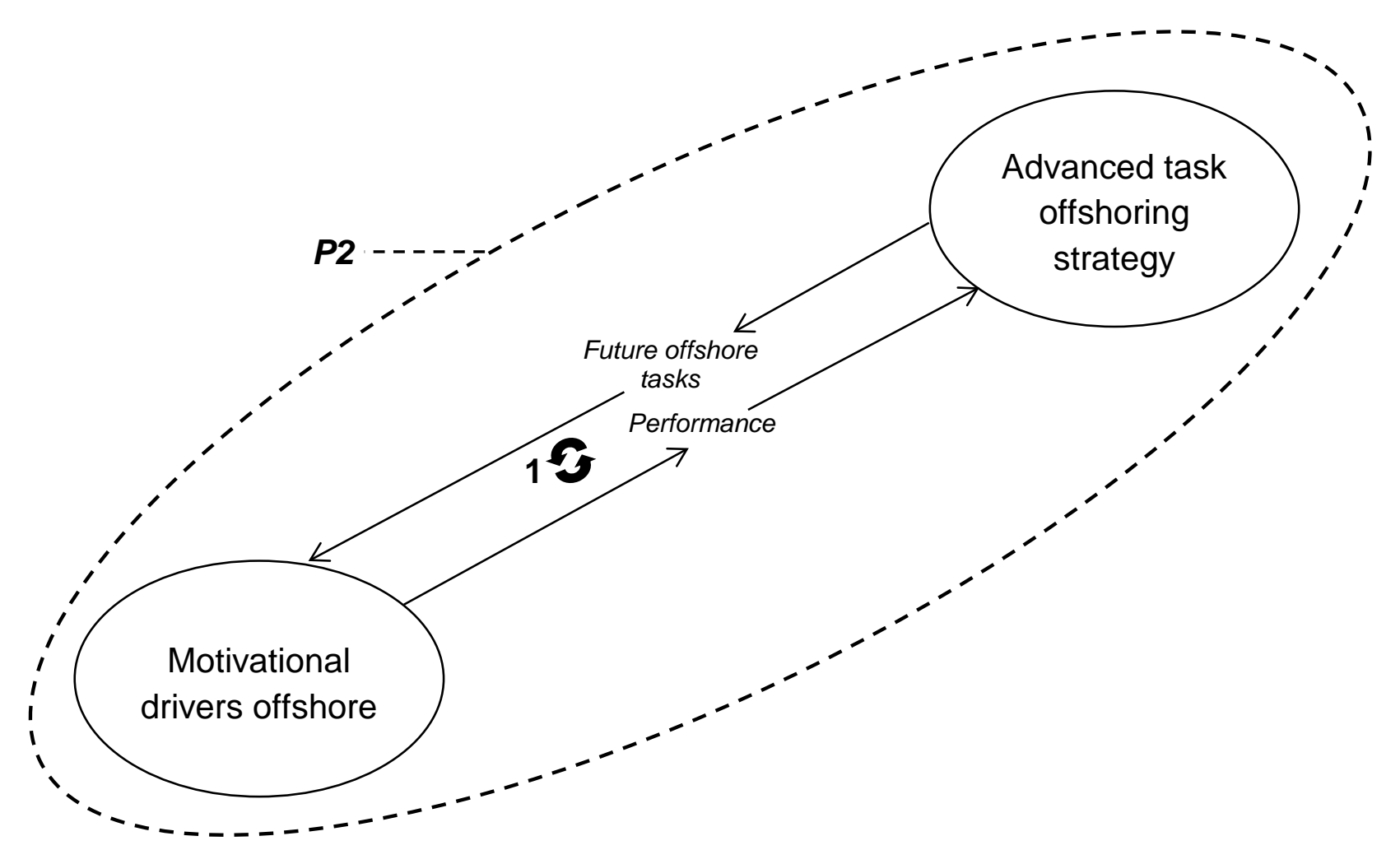


Figure 3c

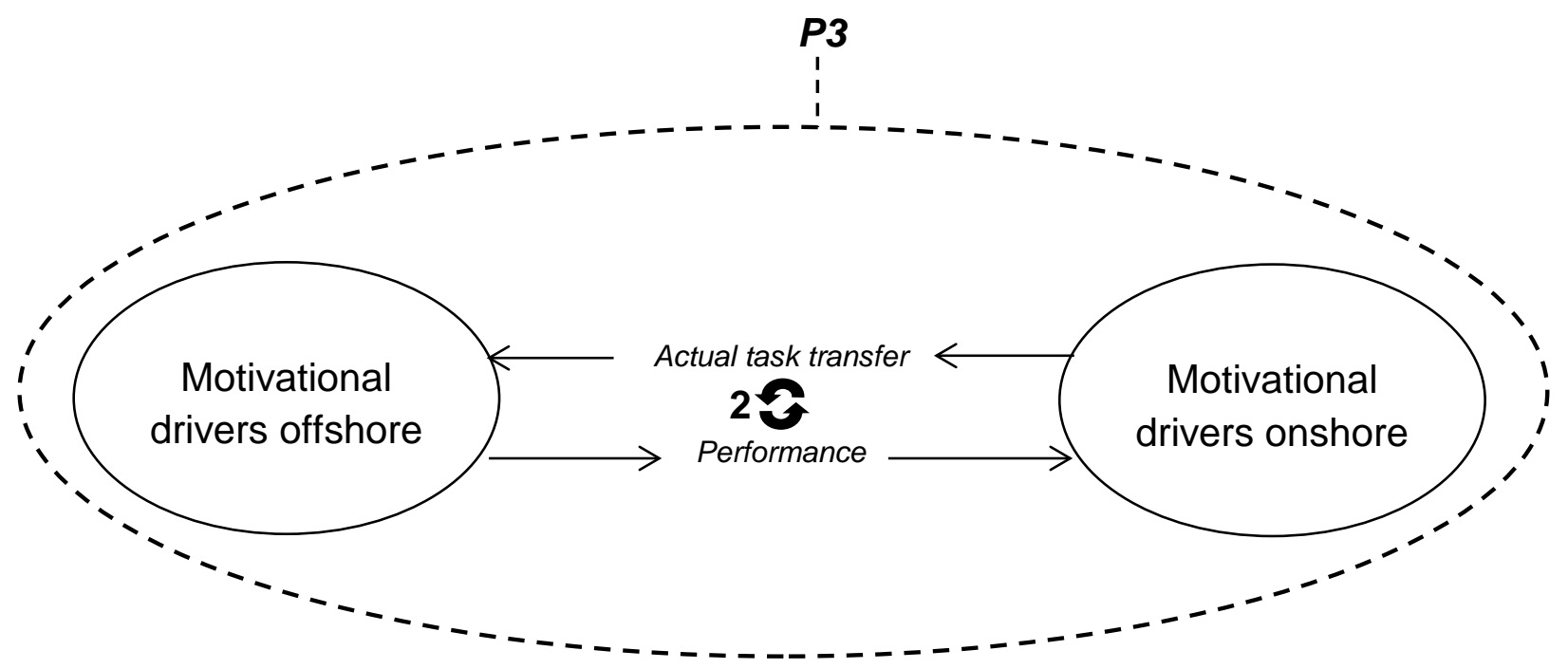




\section{Figure 3d}

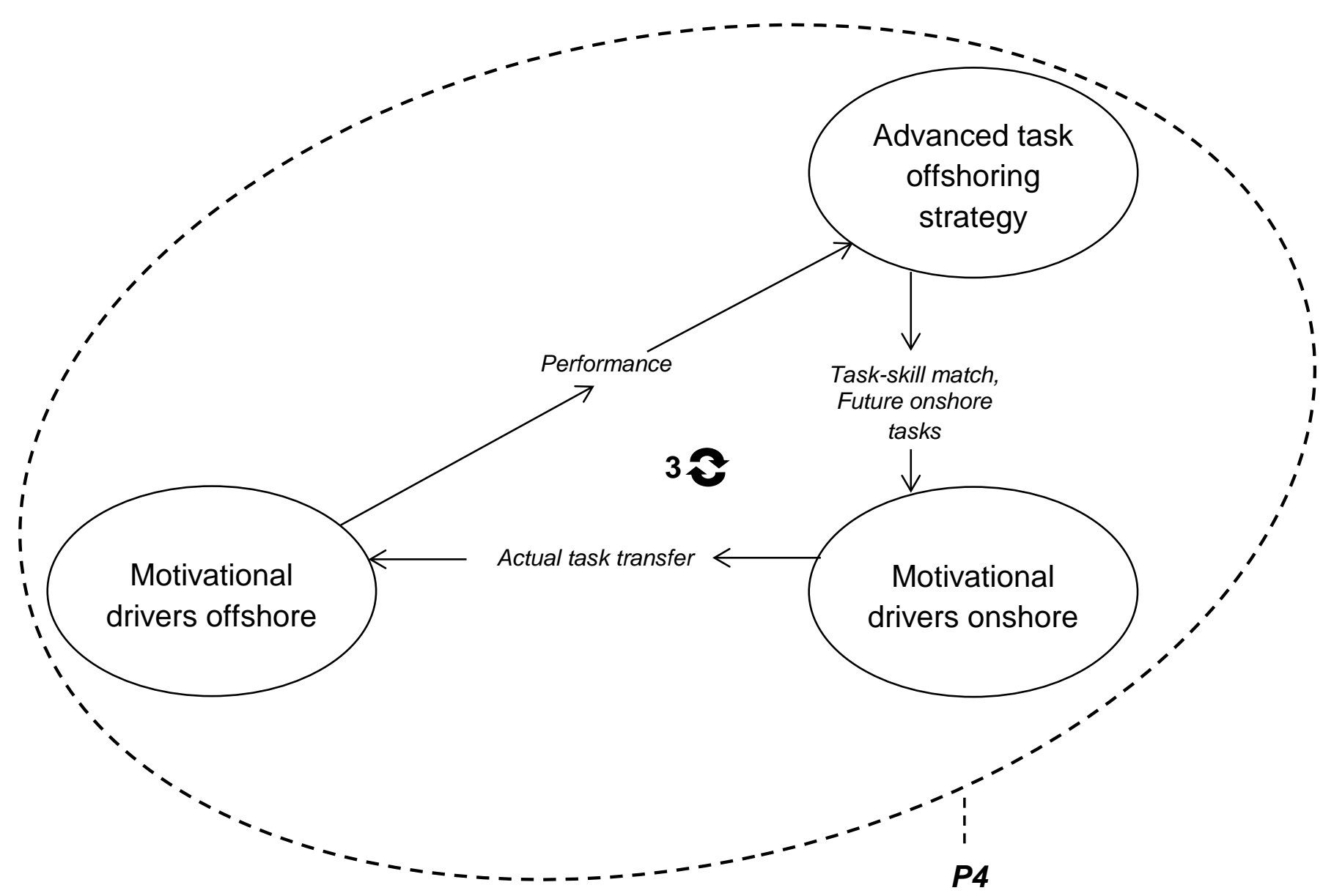


Figure 3e

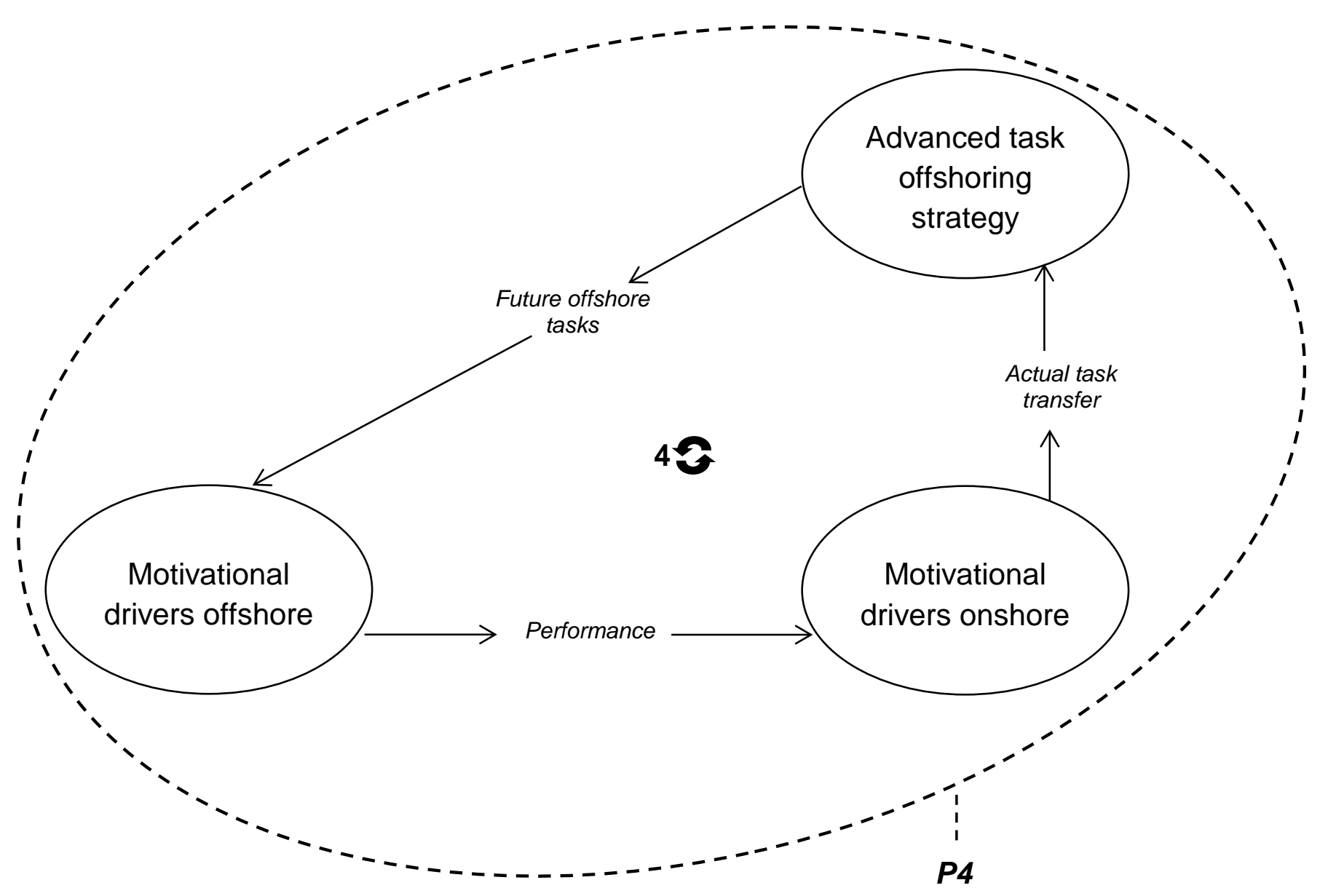


Table 1 Departments and respondents

\begin{tabular}{|c|c|c|c|c|c|c|c|c|}
\hline Company & \multicolumn{4}{|c|}{ ELECTRO } & \multicolumn{4}{|c|}{ PROFSERVICE } \\
\hline Department & \multicolumn{2}{|c|}{ AUTOSAFETY } & \multicolumn{2}{|c|}{ AUTOCONTROL } & \multicolumn{2}{|c|}{ EXPAT-TAX } & \multicolumn{2}{|c|}{ CORP-TAX } \\
\hline Main activity & \multicolumn{2}{|c|}{$\begin{array}{l}\text { Developing electronic control units } \\
\text { for car engines }\end{array}$} & \multicolumn{2}{|c|}{$\begin{array}{l}\text { Developing electronics for } \\
\text { automotive safety systems }\end{array}$} & \multicolumn{2}{|c|}{$\begin{array}{l}\text { Completing UK-related tax } \\
\text { returns for client firms' } \\
\text { expatriates }\end{array}$} & \multicolumn{2}{|c|}{$\begin{array}{l}\text { Completing Tax services for } \\
\text { UK based firms }\end{array}$} \\
\hline Units & Germany & India & Germany & India & UK & India & UK & India \\
\hline \multirow[t]{14}{*}{ Respondents } & \multicolumn{4}{|c|}{ Overall: 32} & \multicolumn{4}{|c|}{ Overall: 30} \\
\hline & 6 & 6 & 9 & 11 & 5 & 7 & 6 & 12 \\
\hline & \multicolumn{4}{|c|}{ Section leader: } & \multicolumn{4}{|c|}{ Senior manager: } \\
\hline & - & 1 & - & 1 & 2 & - & 3 & 1 \\
\hline & \multicolumn{4}{|c|}{ Group leader: } & \multicolumn{4}{|c|}{ Manager: } \\
\hline & 3 & 4 & 1 & 2 & 2 & 3 & 2 & 2 \\
\hline & \multicolumn{4}{|c|}{ Team leader: } & \multicolumn{4}{|c|}{ Assistant manager: } \\
\hline & 2 & 1 & 5 & 3 & - & - & - & 4 \\
\hline & \multicolumn{4}{|c|}{ Team section leader: } & \multicolumn{4}{|c|}{ Tax senior: } \\
\hline & - & - & 1 & 2 & - & 4 & - & 3 \\
\hline & \multicolumn{4}{|l|}{ Engineer: } & \multicolumn{4}{|c|}{ Senior tax team assistant: } \\
\hline & 1 & - & 2 & 3 & 1 & - & 1 & - \\
\hline & & & & & \multicolumn{4}{|c|}{ Tax analyst: } \\
\hline & & & & & - & - & - & 2 \\
\hline
\end{tabular}


Table 2 Offshoring strategy in the ELECTRO and PROFSERVICE departments

Increasing task complexity, non-routineness / level of managerial responsibility

(a) ELECTRO

Tasks:

\begin{tabular}{|c|c|c|c|c|c|}
\hline Department: & Coding & $\begin{array}{l}\text { System integration and } \\
\text { System review for } \\
\text { extant products }\end{array}$ & $\begin{array}{l}\text { System integration } \\
\text { and System review } \\
\text { for new products, } \\
\text { client interface } \\
\text { (Asian clients) }\end{array}$ & $\begin{array}{l}\text { New function } \\
\text { development (Asian } \\
\text { clients) }\end{array}$ & $\begin{array}{l}\text { New function } \\
\text { development, } \\
\text { Client interface (non- } \\
\text { Asian clients) }\end{array}$ \\
\hline AUTOCONTROL & \multicolumn{2}{|c|}{ Currently offshored } & Offshoring in process & Offshoring planned & $\begin{array}{l}\text { To be retained onshore in } \\
\text { the foreseeable future }\end{array}$ \\
\hline AUTOSAFETY & Currently offshored & \multicolumn{2}{|c|}{ Offshoring in process } & Offshoring planned & $\begin{array}{c}\text { To be retained onshore in } \\
\text { the foreseeable future }\end{array}$ \\
\hline
\end{tabular}

- due to complexity and context-

dependency of required

knowledge, location of the client,

Managerial responsibility:

\begin{tabular}{|c|c|c|c|c|c|}
\hline Department: & $\begin{array}{l}\text { Project leadership } \\
\text { (mature products) }\end{array}$ & $\begin{array}{l}\text { Project leadership } \\
\text { (new products for } \\
\text { Asian clients) }\end{array}$ & $\begin{array}{l}\text { Financial liability } \\
\text { (Asian clients) }\end{array}$ & $\begin{array}{l}\text { Project leadership (new } \\
\text { products for non-Asian } \\
\text { clients) }\end{array}$ & $\begin{array}{l}\text { Financial liability (non- } \\
\text { Asian clients) }\end{array}$ \\
\hline AUTOCONTROL & Currently offshored & Offshoring in process & Offshoring planned & \multicolumn{2}{|c|}{ To be retained onshore in the foreseeable future } \\
\hline AUTOSAFETY & Offshoring in process & \multicolumn{2}{|c|}{ No explicit offshoring plan } & \multicolumn{2}{|c|}{ To be retained onshore in the foreseeable future } \\
\hline
\end{tabular}


PROFSERVICE

Tasks:

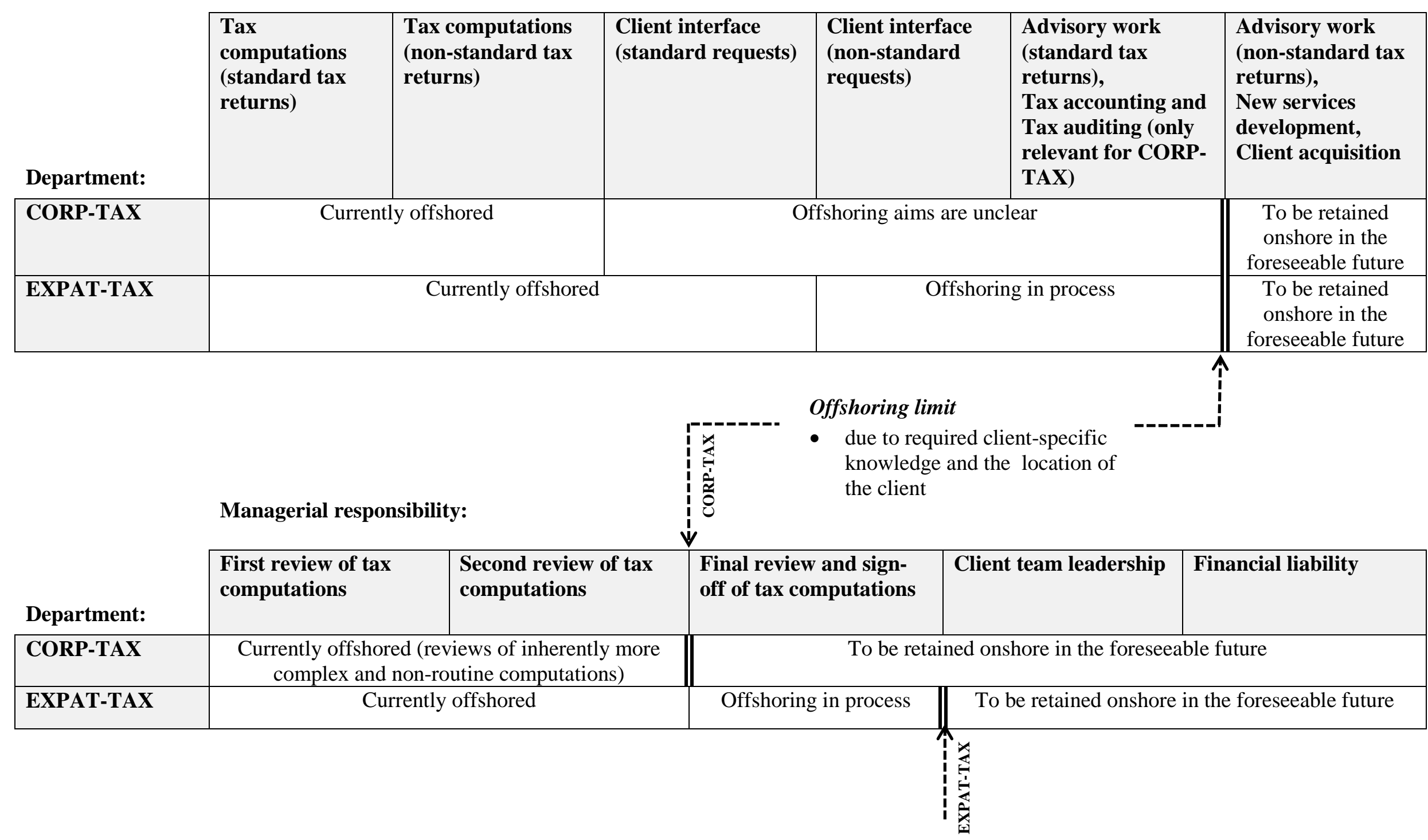


Table 3 Tasks in ELECTRO

\begin{tabular}{|l|l|}
\hline Task & Description \\
\hline Coding & Software coding \\
\hline Software integration & Integrating new software components with existing software \\
\hline System integration & $\begin{array}{l}\text { Integrating the software components into an automotive safety } \\
\text { unit or electronic control unit system, and ensuring that they } \\
\text { function together }\end{array}$ \\
\hline System review & $\begin{array}{l}\text { Evaluating software coding and integration to ensure their } \\
\text { compatibility with automotive safety unit or electronic control } \\
\text { unit systems }\end{array}$ \\
\hline Client interface & $\begin{array}{l}\text { Receiving software and systems requirements from the client, } \\
\text { responding to client requests, and delivering the product to the } \\
\text { client }\end{array}$ \\
\hline New function development & $\begin{array}{l}\text { Designing new functions of an automotive safety or electronic } \\
\text { control unit, typically in response to client requests or problems } \\
\text { with the current product. New functions are commonly defined } \\
\text { in terms of specific software calculation models that are } \\
\text { translated into software. }\end{array}$ \\
\hline
\end{tabular}


Table 4 Tasks in PROFSERVICE

\begin{tabular}{|l|l|}
\hline Task & Description \\
\hline Tax computations & Calculating and producing tax returns \\
\hline Client interface & $\begin{array}{l}\text { Exchanging client specific tax-related information with the } \\
\text { client, and responding to client requests }\end{array}$ \\
\hline Advisory work & $\begin{array}{l}\text { Advising clients on their best options for tax compliance, taking } \\
\text { into account individual client tax structures }\end{array}$ \\
\hline Tax accounting & Preparing accounts that record a client's tax liability \\
\hline Tax auditing & Assessing a client's tax compliance \\
\hline New services development & Creating new types of services to clients \\
\hline Client acquisition & Obtaining new clients \\
\hline
\end{tabular}




\section{Appendix A: Final Interview guide ${ }^{1}$}

[Brief introduction of the research project]

- I examine the collaboration and the transfer of tasks between the onshore and offshore office. I am interested in your personal experience, and concrete examples. Explanation of confidentiality. Recording?

[Background information]

- How long have you been working for the company and in your current role? Could you briefly describe your role?

- Which offshore/onshore colleagues do you work with most frequently? For how long have you been working with each other?

- Could you describe the tasks of offshore and onshore colleagues in your team/project/department?

- To what extent are onshore and offshore tasks interdependent and require frequent communication/coordination?

[General evaluation of collaboration and outcomes]

- How would you rate the success of the onshore-offshore team overall?

- What do you think onshore or offshore colleagues could do to improve the collaboration/ the results, both at employee and management level?

[Actual task transfer/offshoring strategy]

- What kind of tasks have been transferred or are still being transferred from the onshore to the offshore side and vice versa (type of knowledge, ongoing versus one-off, etc.)

- Are further tasks still being transferred, or was it a one-off?

- To what extent are higher level responsibilities transferred to the offshore site?

o higher end tasks,

0 management,

o customer interface, budget/end cost, responsibility towards the end customer

- Are there any plans of transferring them in the future?

[Outcome expectations]

- What consequences does offshoring have for onshore colleagues?

o quality of outputs,

o efficiency, coordination effort

0 nature of tasks

0 threat to tasks and jobs?

o loss of core competences?

- Do you think that onshore colleagues' attitudes towards these consequences of offshoring affect the way they deal with their offshore colleagues/transfer tasks/transfer knowledge?

- Does the allocation of responsibility between onshore and offshore sites/level of transferred tasks make a difference for

o The offshore colleagues' background understanding

o For offshore colleagues' career prospects/attrition

o For offshore colleagues' motivation to absorb knowledge/take responsibility

o For onshore colleagues' fears of losing tasks or even jobs?

o For onshore colleagues' motivation to provide higher end tasks/knowledge

Do you think it is possible to achieve satisfactory task transfer/ performance? What does it depend on?

What advice would you give to onshore and offshore employee at your firm, both at management level and working level?

\footnotetext{
${ }^{1}$ We have abbreviated the interview guide, to include only the questions that are relevant for this paper.
} 
Appendix B: Advanced task offshoring at ELECTRO and PROFSERVICE: Illustrative quotes

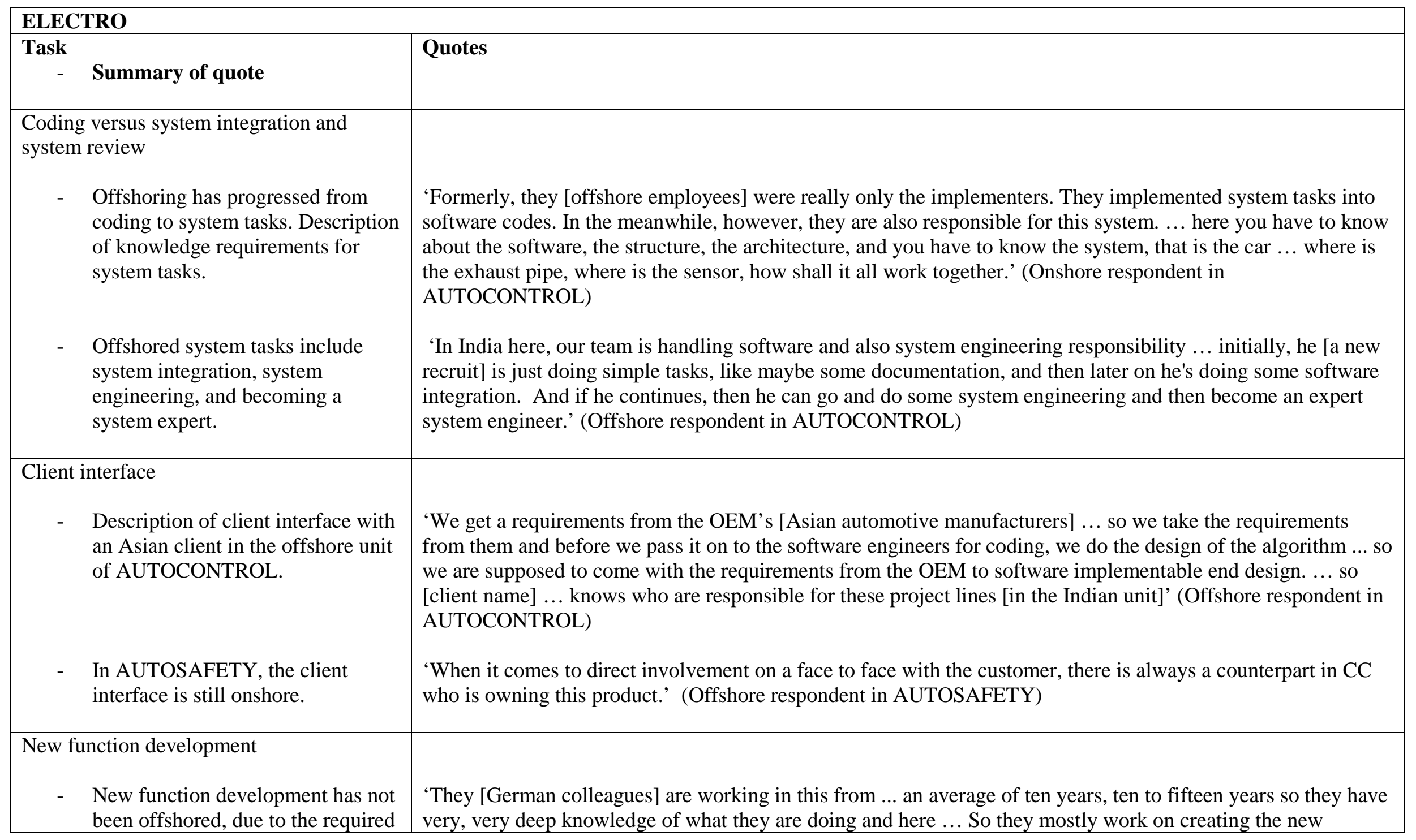




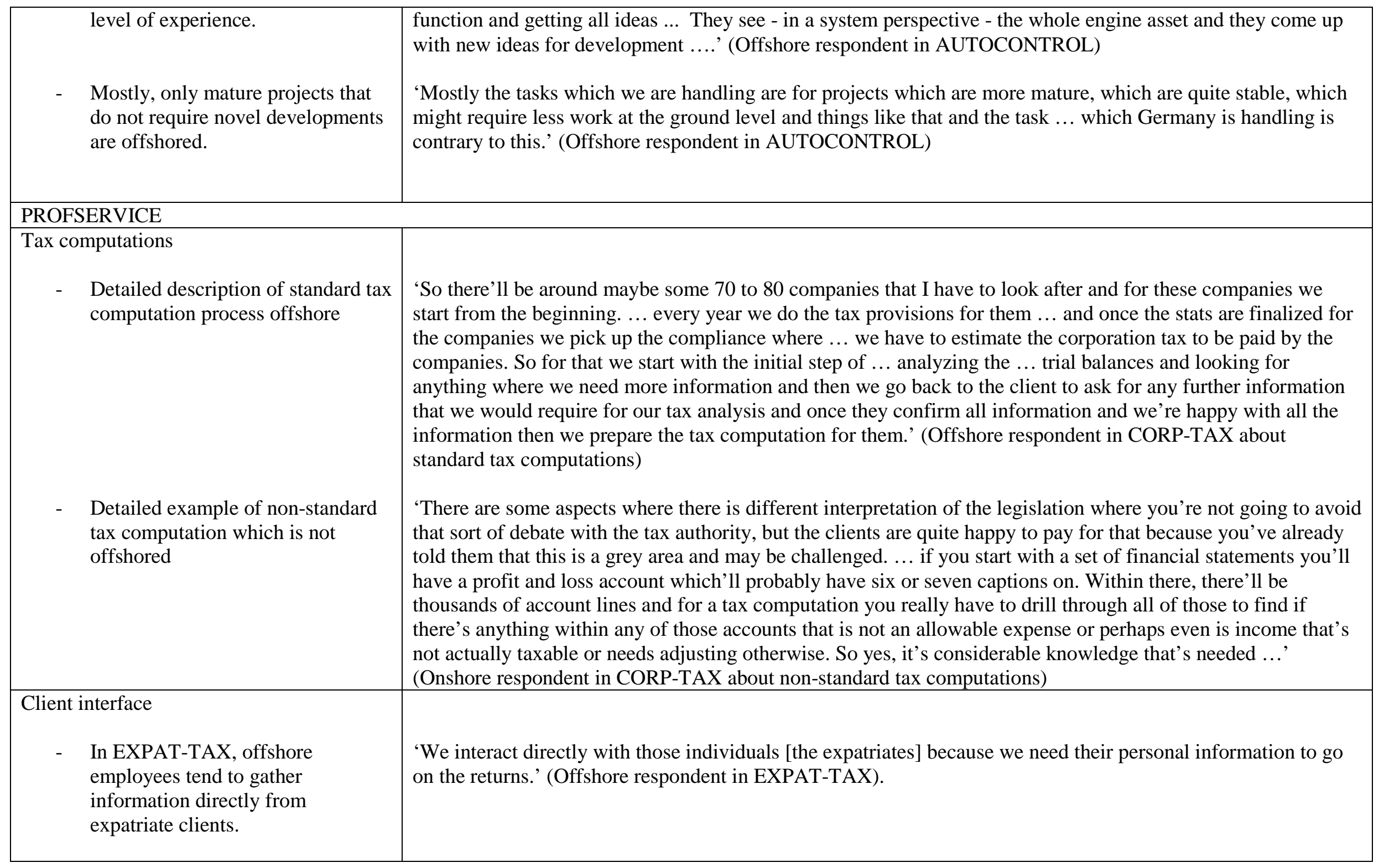




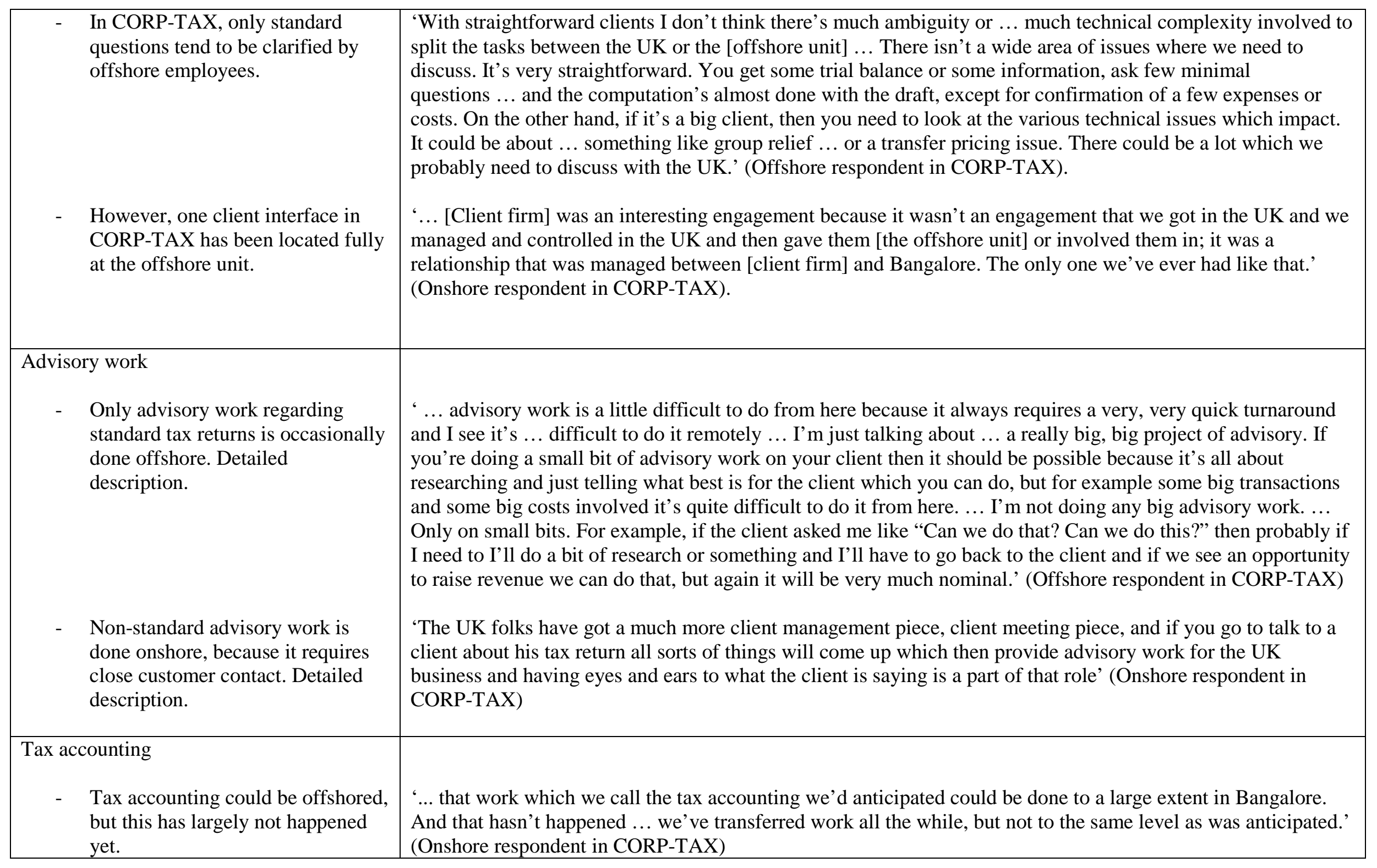




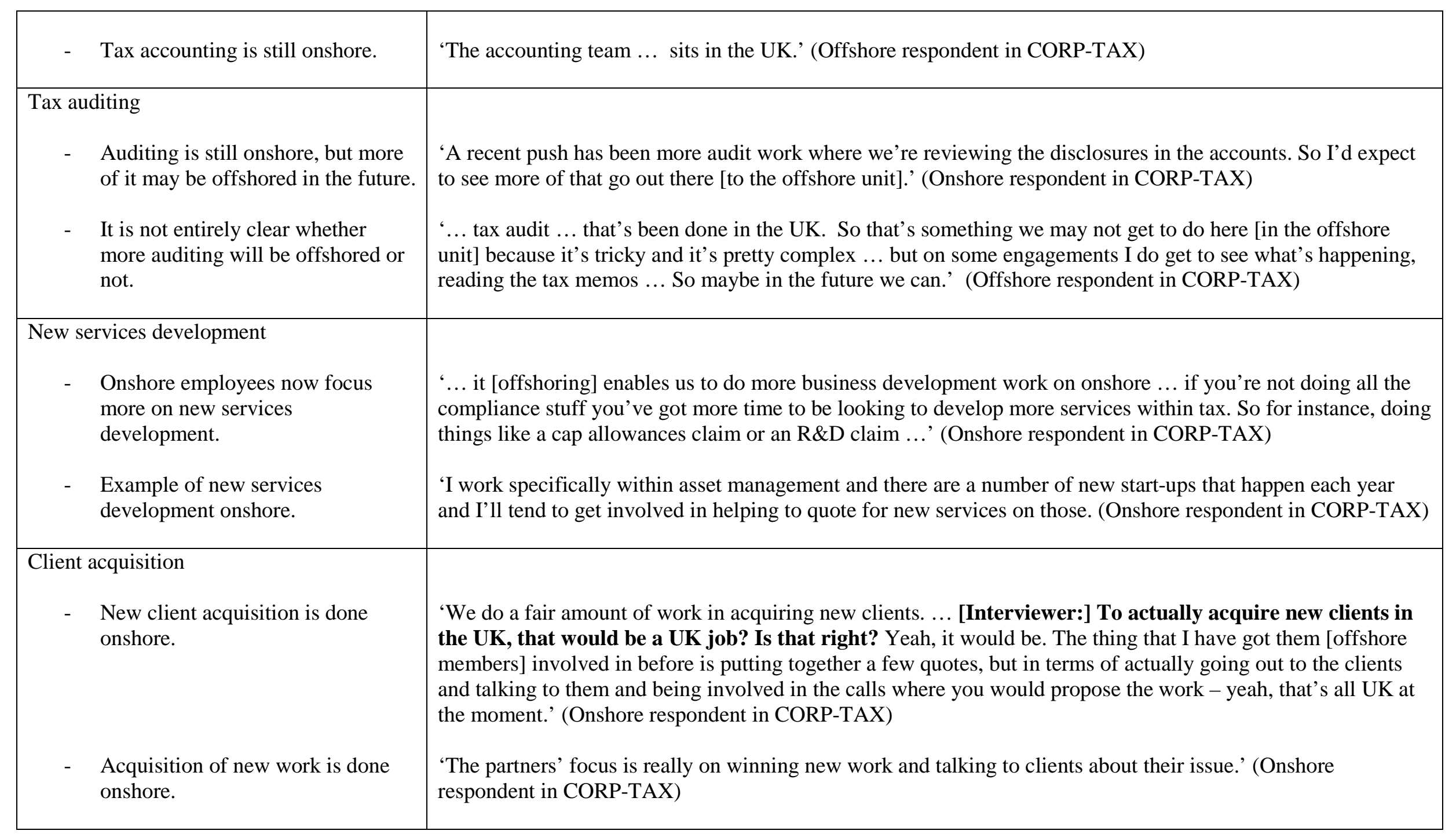

